\title{
Mangrove ecological services at the forefront of coastal change in the French Overseas Territories
}

\author{
Trégarot Ewan ${ }^{1}$, Caillaud Anne ${ }^{2}$, Cornet Cindy C. ${ }^{1}$, Taureau Florent ${ }^{3}$, Catry \\ Thibault ${ }^{4}$, Cragg Simon M. ${ }^{5}$, Failler Pierre ${ }^{1}$. \\ ${ }^{1}$ Centre for Blue Governance, Department of Economics and Finance, Portsmouth Business \\ School, University of Portsmouth, Richmond Building, Portland Street, Portsmouth PO1 3DE, \\ United Kingdom. \\ ${ }^{2}$ IUCN French National Committee, Paris, France \\ ${ }^{3}$ Private consultant in coastal environment, 35600, Sainte-Marie, France \\ ${ }^{4}$ ESPACE-DEV, UMR 228 IRD/UM/UR/UG/UA, Institut de Recherche pour le Développement \\ (IRD), Montpellier, France. \\ ${ }^{5}$ Centre for Blue Governance, Institute of Marine Sciences, University of Portsmouth, Ferry \\ Road, Portsmouth PO4 9LY, United Kingdom
}

\begin{abstract}
Mangroves are located at the land-sea interface and are therefore confronted with human settlement in the coastal areas and associated pressures and uses. This unique habitat provides important ecosystem services to coastal communities worldwide, but the global decline of their surface area and their degradation over the past decades has put coastal communities even more at risk from the effects of climate change. This paper aims to present the first ecosystem services valuation of the mangroves of the French Overseas Territories. We provide the economic value of mangroves for coastal protection, carbon sequestration, water purification and fish biomass production. We coupled a geospatial analysis of mangrove's distribution with the characterisation of land artificialisation behind mangroves. Then we developed a vulnerability index based on multiple indicators of exposure to environmental and anthropogenic stressors, mangroves' sensitivity to pressures, and mangroves' adaptive capacity to adjust their production functions accordingly. We estimated the monetary value of regulation and support services provided by mangroves in French overseas territories to be on average EUR 1.6 billion annually, $60 \%$ of which is carbon sequestration, $28 \%$ coastal protection, $7 \%$ water purification and $6 \%$ fish biomass production. When considering mangroves services without the vulnerability adjustment, the total value for those services would reach EUR 2 billion per year. Although much of the spatiotemporal variability in mangrove functioning could not be considered given the spatial scale of our study, these results demonstrate the value and socio-economic importance of mangroves to face and adapt from the effects of coastal change, at local and national scales, but also highlight the loss of services due to their vulnerability. This paper emphasises on the value of ecosystem services provided by mangroves to face coastal change so that a service-based approach to conservation would plead for increased national investment into their protection.
\end{abstract}

Key words: Mangroves; Vulnerability index; Coastal protection; Carbon sequestration; Water purification; Fish biomass production

* Corresponding Author: ewan.tregarot@port.ac.uk 


\section{Graphical Abstract}

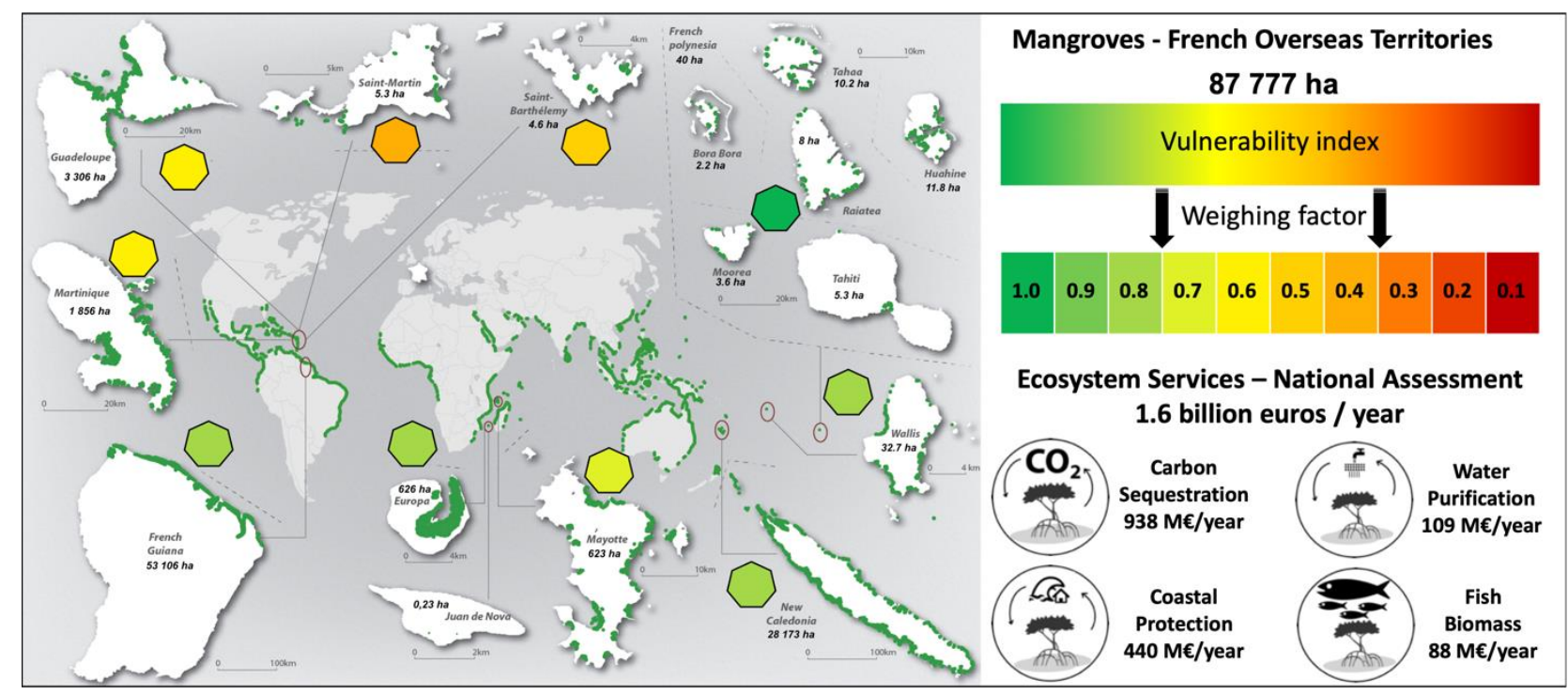

\section{Highlights}

- Mangroves in France are spread over nine overseas territories and three oceans

- Ecosystems' services provision should decrease when their vulnerability increases

- We developed a vulnerability index for mangroves and integrated it in the valuation of their regulating services

- We estimated mangroves' services to mitigate coastal change at $€ 1.6$ billion per year

- Ecosystem services provisioning is the lowest in the French West Indies due to higher vulnerability 


\section{Introduction}

Mangrove ecosystems globally are expected to be substantially influenced by climate change-related physical processes in the future (Li et al., 2015; Ward et al., 2017). At the land-sea interface, the complex functioning of those forests under diverse and changing environmental settings (i.e., species composition, tidal regime, precipitation, temperature, salinity, anthropogenic pressures, sea-level rise, sediment inputs, etc.) makes it difficult to anticipate future coastal changes. Yet, mangroves are one of the most effective ecosystems on Earth to mitigate and to adapt to the effects of climate change (Alongi, 2008; Dahdouh-Guebas et al., 2005; Mazda et al., 2006; Taillardat et al., 2018). Satellite altimetry has shown that global mean sea level has been rising at a rate of $3 \mathrm{~mm} \mathrm{yr}^{-1}$ on average since 1993 (Ablain et al., 2017), and this rate is accelerating by $0.084 \mathrm{~mm} \mathrm{yr}^{-1}$ on average, meaning sea-level rise could reach up to $65 \mathrm{~cm}$ by 2100 (Nerem et al., 2018). Although at smaller coastal scale, this very global trend will be affected either positively or negatively by atmospheric surges, tidal patterns and nearshore wave regimes (Idier et al., 2019; Melet et al., 2018), marine transgression will undoubtedly have a significant impact on mangroves that are dependent on sea level. Paleoenvironmental studies have shown that mangroves are able to adapt and maintain themselves during periods of sea-level rise, thanks to two distinct processes: 1) the accumulation/accretion of sediment allowing to counterbalance rising waters on the one hand, and 2) shifting inland when existing sites become flooded on the other hand (Ellison, 2008; Woodroffe et al., 2016). Therefore, the topography of flooded lands, sediment supply by rivers and human infrastructures' density behind mangroves are three determining factors in predicting responses of mangroves to sea-level rise. From pristine lowelevated islands to densely-populated volcanic islands and continental mangroves, not all mangroves are thus equal in the face of rising sea levels and storm surges (Ellison, 2015). 
Scattered between the Lesser Antilles, Amazonia, the Indian Ocean and the Pacific Ocean, mangroves in French Overseas territories are widely distributed across the Earth and therefore, grow under many different geomorphic settings, environmental conditions and anthropogenic pressures. For instance, in French Guiana, an open and very muddy coastal environment, mangroves distribution depends on sediment inputs from the Amazon with alternating periods of transgression and erosion (Plaziat and Augustinus, 2004). In Saint-Martin on the other hand, mangroves are spatially limited to internal lagoons and have mainly been degraded due to historic activities of salt extraction in evaporation ponds, urbanisation, and more recently by hurricane Irma in 2018 (Walcker et al., 2019). In Europa then (Scattered Islands - Indian Ocean), mangroves thrive in a pristine, marine dominated, yet semi-arid, environment, without any river inputs (Fromard 2014). Mangroves' spatio-temporal dynamics and ecosystem functioning are thus unique and complex in each territory. The impact of any changing environmental parameters and anthropogenic forcing remains to be accounted for. Advanced modellings are, therefore, needed to understand the cumulative effects of multiple risks on mangroves, and to predict their contextdependent response to climate change and other anthropogenic pressures (Furlan et al., 2019; Gilman et al., 2008).

In the present study, we examined the vulnerability of mangroves to anthropogenic drivers and global changes to adjust their provision of services to humans, based on the assumption that an increase in habitat vulnerability is likely to decrease the supply of ecosystem services (Schröter et al., 2005). Indeed, mangroves exposed to stress are more sensitive to disturbances, have reduced adaptive capacities, and are therefore less likely to provide the full suite of services healthy mangroves usually offer. In the same vein as considering the ecological condition of an ecosystem to adjust the production function (Culhane et al., 2020; Failler et al., 2015; Trégarot et al., 2017) or the risk to ecosystem services supply (Culhane et al., 2019), the benefit of this approach is to provide a more precise valuation of ecosystem services and to shed light on the loss 
of services due to the current pressures. We focused in particular on mangroves' climate change adaptation and mitigation potential, through the services of coastal protection (Alongi, 2008;

Dahdouh-Guebas et al., 2005; Mazda et al., 2006), carbon sequestration (Donato et al., 2011; Ezcurra et al., 2016; Sasmito et al., 2020) as well as functions servicing the growing population in coastal areas, namely fish biomass production (that accounts for the nursery function - Igulu et al., 2014) and water purification (improvement in water quality - Adame et al., 2019).

This study provides the first ecosystem services valuation of all mangrove forests present in the French Overseas territories. This preliminary assessment, whose method is applicable to all territories, is a pivotal milestone toward the consideration of local contexts. Indeed, environmental and socio-economic contexts are very different from one region to another and within each territory for the reasons mentioned before. A standardized assessment method could never fully apprehend all the processes involved in the provision of services. Nonetheless, understanding mangrove services in all French overseas territories remains pertinent as it may support national interest, and therefore, policies and budget dedicated to their protection, which would then trickle down locally. The assessment of mangroves' vulnerability is a first step to the comprehension of the variability observed in mangroves forests across territories, and while it has been developed before (e.g. Ellison et al., 2015; Ventura and da Cunha Lana, 2014), and tested in the valuation of ecosystem services for other coastal marine ecosystems (e.g. Cabral et al., 2015), vulnerability indicators such as the ones developed here have never been used to adjust the assessment of mangroves ecosystem services to our knowledge.

In this paper, we first present the distribution of mangrove forests in French Overseas territories. Then, we provide a tailored assessment of mangroves' production functions using the vulnerability index that we developed specifically for this exercise and present the monetary value per territories of each ecosystem services. Finally, we were able to compare all nine territories 
according to their environmental and socio-economic characteristics, to draw conclusions for management and policy decisions at local and national scales.

\section{Methods}

\subsection{Study area}

French Overseas territories are administered by France but are located outside of the European continent. These territories have different legal statuses. They are all represented in the French Parliament except for districts of the French Southern and Antarctic Lands (TAAF) that do not have permanent populations (Table 1). Mangroves are naturally present in nine territories and introduced in French Polynesia. 
Table 1

Socio-economic and demographic characteristics of French Overseas territories with mangroves.

\begin{tabular}{|c|c|c|c|c|c|c|}
\hline $\begin{array}{l}\text { French Overseas } \\
\text { territory }\end{array}$ & Region & EU Overseas Status & $\begin{array}{l}\text { GDP per } \\
\text { capita }^{\mathrm{g}}\end{array}$ & Population & $\begin{array}{r}\text { Pop. } \\
\text { Density } \\
(\text { hab./km²)* }\end{array}$ & $\begin{array}{r}\text { Yearly \% change } \\
\text { (averaged over } 10^{\text {years) }}{ }^{\mathrm{g}}\end{array}$ \\
\hline French Guiana & Amazonia & Overseas Region & $16,287 €$ & $268,700^{a}$ & 3.2 & $2.5 \%$ \\
\hline Martinique & Lesser Antilles & Overseas Region & $23,274 €$ & $372,594^{\mathrm{a}}$ & 330.3 & $-0.7 \%$ \\
\hline Saint Martin & Lesser Antilles & Overseas Region & $14,700 €$ & $35,334^{b}$ & 409.2 & $0.1 \%^{\mathrm{h}}$ \\
\hline Saint Barthelemy & Lesser Antilles & Overseas Country and Territory & $35,700 €$ & $9,961^{b}$ & 408.0 & $1.75 \%$ \\
\hline Mayotte & Indian Ocean & Overseas Region & $8,980 €$ & $250,143^{\mathrm{a}}$ & 668.8 & $3.1 \%$ \\
\hline Wallis and Futuna & Pacific Ocean & Overseas Country and Territory & $10,100 €$ & $11,558^{\mathrm{d}}$ & 81.2 & $-2.0 \%$ \\
\hline French Polynesia & Pacific Ocean & Overseas Country and Territory & $17,035 €$ & $275,918^{\mathrm{c}}$ & 66.2 & $0.4 \%$ \\
\hline
\end{tabular}


Beyond the socio-economic and demographic characteristics, mangroves are present in very different environmental settings. In French Guiana and Mayotte, there are coastal and estuarine mangroves. In French Guiana, mangroves experience alternating periods of rapid and extensive progradation or erosion depending on sediment inputs from the Amazon (Plaziat and Augustinus, 2004). In the Lesser Antilles (Martinique, Guadeloupe), two types of mangroves are present: alluvial and colluvial mangroves, whether they develop along river shores or in sheltered bays, respectively (Roussel and Rivasseau, 2008). In Saint-Martin and Saint-Barthelemy, mangroves are mostly present in internal lagoon. In Europa (Scattered Islands), coral lagoon mangroves develop in semi-arid conditions with low freshwater availability (Fromard 2014). Distinct morphotypes of mangroves are found in New-Caledonia depending on their locality: estuaries, deltas, bays, coast, and small islet. In Wallis, mangroves are mainly present in small muddy bays.

French Polynesia is a particular case because mangroves are not indigenous to this territory. One species of mangrove (Rhizophora stylosa) from New-Caledonia was introduced in the 1930s on the west coast of Moorea, Haapiti, to allow the development of the Crassostrea sp. oyster but the later never acclimated. However, mangroves proliferated in Moorea and spread to the nearby islands of Tahiti, Raiatea, Tahaa, Huahine, and Bora Bora (Cavaloc, 1988; Fauchille 2003; Iltis and Meyer, 2010; Taureau, 2019). We decided to keep the mangroves of French Polynesia in our analysis to shed light on the services rendered, despite being invasive. However, the disservices associated with the replacement of indigenous species such as Paspalum vaginatum saltmarshes and sub-mangrove forests should also be considered. A cost-benefit analysis would provide a more accurate valuation of these invasive mangroves, but we were not able to assess these disservices here because of a lack of data. 
The valuation of ecosystem services provided by mangroves required a vast amount of data, analysis and literature review. An operational flow chart presents the different steps of our evaluation (Fig. 1), further described in the following sections. 
Fig. 1. Operational flow chart for the assessment of ecosystem services provided by mangroves in the French Overseas territories.

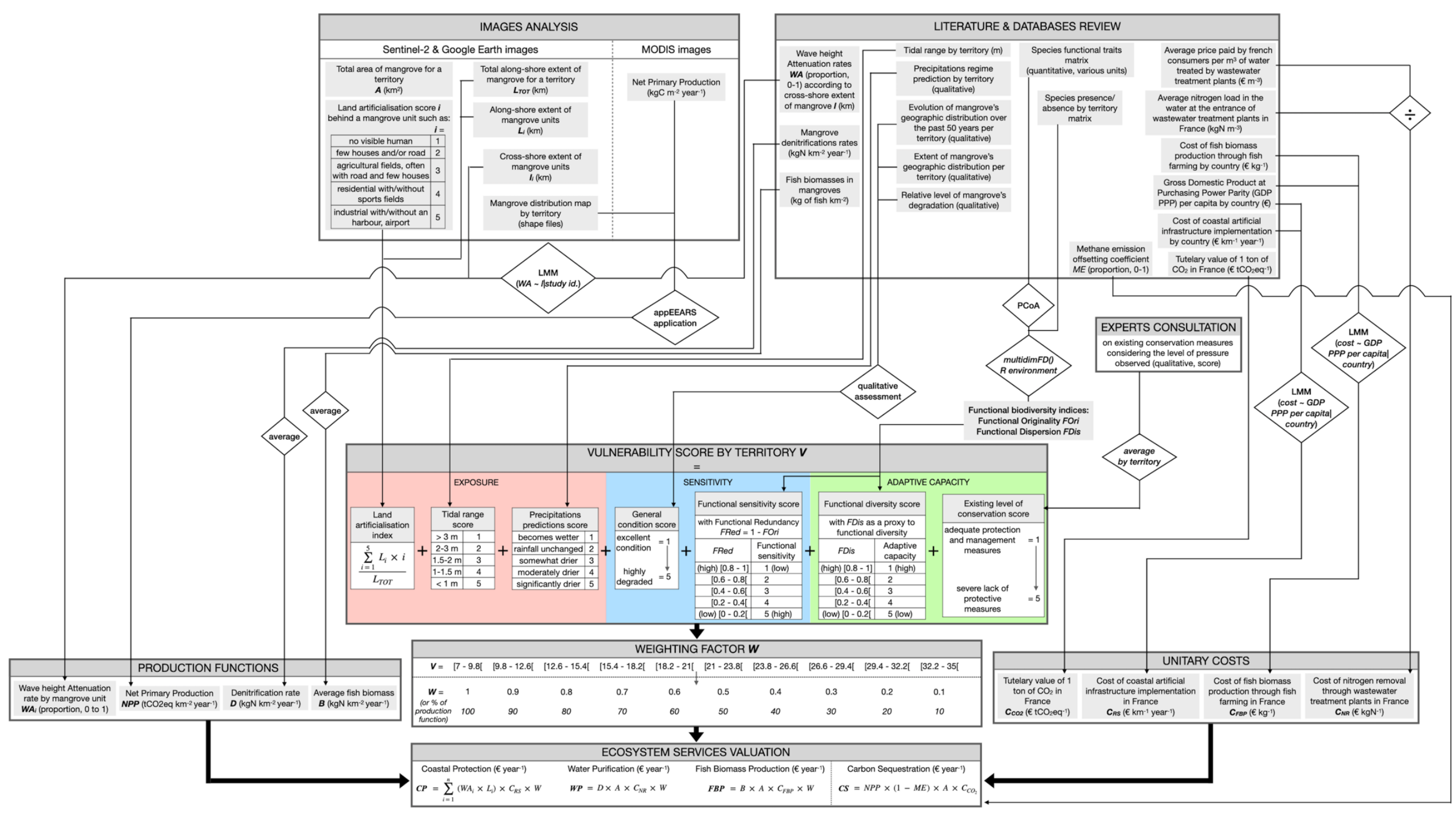




\subsection{Mapping of mangroves}

According to the previous national estimate made in 2016 (Taureau, 2017), the French overseas territories account for a little over 90,000 ha of mangroves using the images from the American Landsat-8 (OLI) satellite - made available by the United States Geological Survey whose sensor has a spatial resolution of $30 \mathrm{~m}$ (i.e. one pixel of $900 \mathrm{~m}^{2}$ ). This harmonized assessment (identical data and methods regardless of the territory) nevertheless suffered from several limitations, and in particular insufficient spatial resolution to detect and map mangrove massifs representing small areas. Since then, the satellite imagery offer has grown considerably, in particular thanks to the Sentinel project developed by the European Space Agency (ESA), and the deployment since 2015 of a series of specialized and complementary sensors, in particular the sensor Sentinel2. These new Sentinel-2 satellite data offer the opportunity to significantly improve the accuracy of the 2016 mapping, both in terms of planimetric accuracy (improvement of the contours of the mangrove delineation) and in the detection of smaller massifs with a spatial resolution of $10 \mathrm{~m}$.

We updated the mangrove mapping using a mixt approach combining Sentinel-2 images from 2020 and manual photo interpretation to adjust the contours (see Figure S1 in Supplementary Materials for the operational flow-chart). This update was done for French Guiana, New Caledonia, Guadeloupe, Martinique, Mayotte and Europa (Scattered Islands), representing 99\% of all French mangroves. Although the level of precision cannot be determined due to photo-interpretation source of error, the increase in spatial resolution provided by Sentinel-2 allows to minimize the presence of mixed pixels. Moreover, the precision of mangrove contours and the detection of the smallest patches is significantly improved than with Landsat-8 (previously used for the national map of mangroves) for which the overall precision was around 90\% $\pm 5 \%$ (Taureau, 2017). Based on the confusion matrix of Sentinel-2 classification (Taureau, 2017; Taureau, 2019), we can conservatively assume an overall accuracy of $92 \%$ in the French Overseas territories. However, it is not always easy on very high-resolution images to determine the limit of the mangrove with the rest of the 
vegetation, especially in French Guiana. Therefore, photo-interpretation should be perceived as a complementary approach to the Otsu classification (Otsu, 1979) but does not replace the necessity for ground truthing associated to any supervised, unsupervised or photo interpretation of remote sensing imagery, especially where spectral signatures of mangroves may look like the ones observed over surrounding flooded or white-sand forests (Alatorre et al., 2011; Wang et al., 2019).

For territories with minimal mangrove extents such as French Polynesia, Wallis-and-Futuna, Saint-Martin and Saint-Barthelemy, we mapped the mangroves separately based on manual photointerpretation of Google Earth images from 2018, based on previous studies where mangrove areas had been previously identified (Iltis and Meyer, 2010; Salvat et al., 2008; Taureau, 2017).

After the mapping of mangroves, we used Google Earth images to extract the total alongshore extent of mangroves per territory, the alongshore and cross-shore extents of each mangroves' units (described in Fig. 2).

\subsection{Ecosystem vulnerability and production function weighting}

We assessed the vulnerability of mangroves $(V)$ considering the following three factors: exposure to environmental and anthropogenic stressors, associated sensitivity, and related adaptive capacity following the general approach of Ellison (2015). We chose seven parameters (most of them differ from Ellison 2015) to assess these factors, and assigned a score to each of them (from 1 to 5), based on existing literature. Then we added up all scores to obtain a global vulnerability score for each territory, where 1 corresponds to a low vulnerability and 5 to a high one. Next, to adjust the production function of ecosystem services for each territory, a weighting factor $(W)$ was attributed according to the vulnerability score of the territory (Fig. 1) as follow: mangroves that are highly vulnerable $(V=35)$ would provide only $10 \%(W=0.1)$ of the

production function supplied by mangroves in pristine condition $(V=7 ; W=1.0)$. 
Given the invasive character of mangroves in French Polynesia, we decided not to include this territory in the assessment of a vulnerability index and therefore provided a score of 1.

\section{Exposure}

We considered three parameters to assess exposure (Fig. 1):

1) Tidal range ( $>3 \mathrm{~m}, 2-3 \mathrm{~m}, 1.5-2.0 \mathrm{~m}, 1-1.5 \mathrm{~m},<1 \mathrm{~m})$ considering that microtidal coasts are more vulnerable to storm impacts and Sea Level Rise (SLR) than macrotidal coasts due to their lower elevation capital (Ellison, 2015; Lovelock et al., 2015; Ward et al., 2016). The tidal ranges were retrieved from the global database (https://maree.shom.fr).

2) Precipitation regimes predictions (becomes wetter, rainfall unchanged, somewhat drier, moderately drier, significantly drier) considering that changing precipitation regimes can affect the growth rate and productivity of mangroves. Hence a decrease in precipitation regime, associated with high evaporation, can result in an increase in the soil salinity with a detrimental effect on seedling survival, productivity and growth rates (Ward et al., 2016), while increased precipitation can increase mangrove productivity and resilience to SLR by reducing pore-water salinity and sulfate concentration, and increasing riverine discharge and sediment inputs (Gilman et al., 2007; Ranasinghe et al., 2013). Changes in precipitation were sourced from Pendergrass et al. (2017). The two former parameters follow the methodology of Ellison (2015), and we assigned scores accordingly (see Fig. 1).

3) Artificialisation of the land behind mangroves, considering that the level of artificialisation at the vicinity of mangroves is a good indicator of anthropogenic pressures (organic and chemical pollution, waste, land-use change, exploitation, etc.). To assess this parameter, we characterised the presence and the type of man-made infrastructure behind mangroves in a cross-shore direction through a photo analysis of high-resolution images from Google Earth. Mangroves units were identified according to their respective categorisation of 
land artificialisation, their along-shore extent was measured, and we assigned a score $i$ for each unit that corresponded to the following five categories: (A) no visible human presence - score of 1; (B) few houses and/or road- score of 2; (C) agricultural fields - often with a road and few houses - score of 3; (D) residential with/without sports fields- score of 4; (E) industrial with/without a harbour, airport - score of 5 (Fig. 2).

$$
\text { Land artificialisation index }=\frac{\sum_{i=1}^{5} L_{i} \times i}{L_{t o t}}
$$

With $L_{i}(\mathrm{~km})$ the along-shore extent of a mangrove unit with the score $i$ and $L_{t o t}(\mathrm{~km})$ the total along-shore extent of mangroves for a territory.

Fig. 2. Classification of land artificialisation behind mangroves and assigned vulnerability scores Google Earth excerpts are from Martinique (A, D), Mayotte (B, E) and New-Caledonia (C).

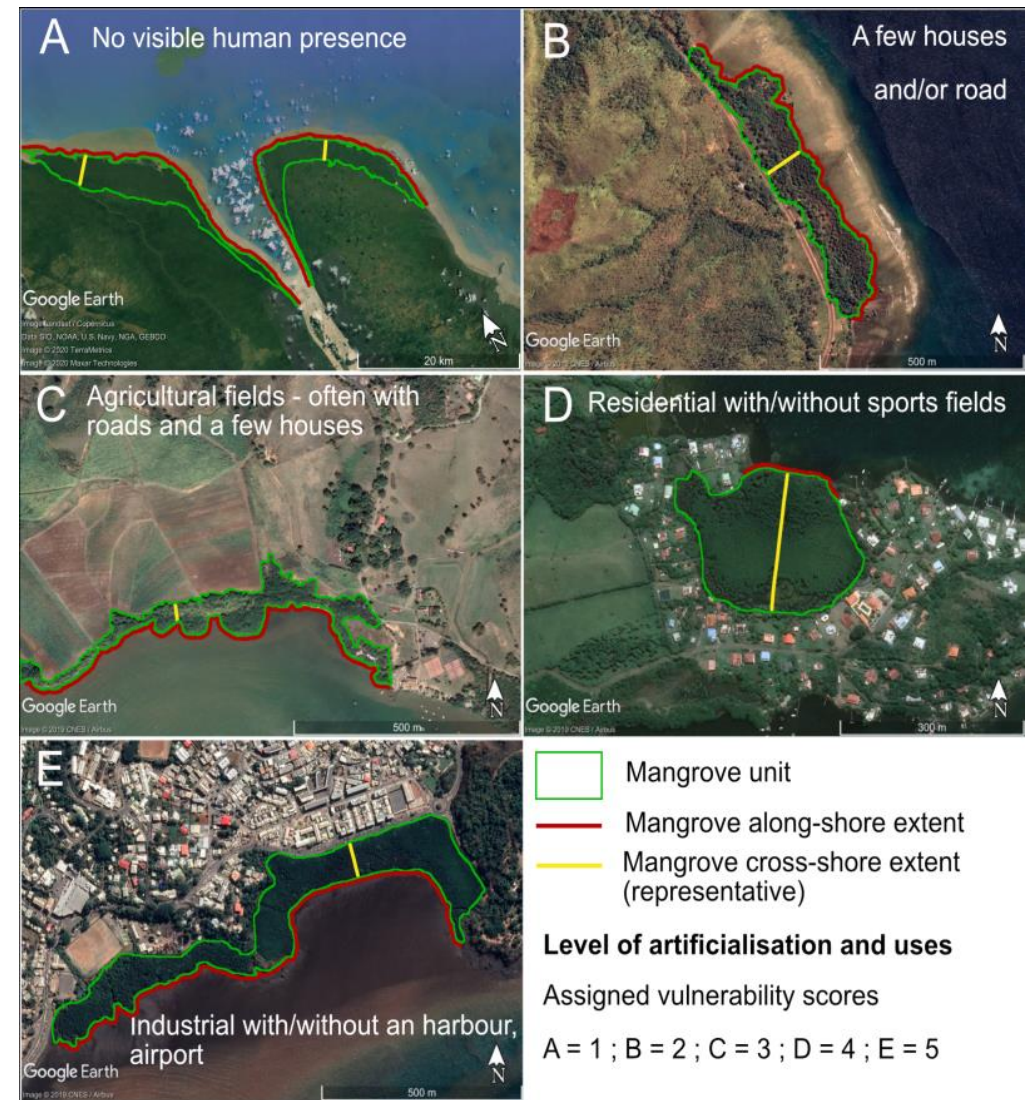




\section{Sensitivity}

We assessed the sensitivity through two parameters: the general condition of the mangrove forest, and its functional sensitivity (Fig. 1). Scores of mangroves' general condition for each territory were based on the review by Roussel and Rivasseau (2008) and considering the following three criteria: trend in the evolution of mangrove's geographic distribution over the past 50 years at the scale of a territory, extent of mangrove's geographic distribution, and relative level of mangrove ecosystem degradation (Criterion A, B and C respectively of IUCN, 2015). Those criteria are among the ones currently being used for the IUCN Red List of Ecosystems assessments (IUCN French Committee, 2017). A score of 1 was assigned to mangroves in excellent condition (i.e. no apparent reduction in the mangrove's geographic distribution over the past 50 years, widespread geographic distribution and no to low degradation of the mangrove's ecosystem), whilst a score of 5 was assigned to highly degraded mangroves (i.e. reduction by at least $50 \%$ of the mangrove's geographic distribution over the past 50 years, restricted geographic distribution and high degradation of the mangrove's ecosystem).

To assess the functional sensitivity of mangroves, we measured the functional redundancy (as opposed to the functional originality) of mangroves in each territory as a proxy. Functional redundancy occurs when multiple species contribute similarly to ecosystem functions, such that redundant species may be able to functionally compensate for the decline or loss of one or more species (Naeem and Li, 1997; Walker, 1995). Therefore, the loss of species would not significantly impact the functioning of the ecosystem until the last member of a functionally redundant group is lost. The loss of that last member could, however, lead to the complete loss of essential ecosystem functions and a shift of the ecosystem to an alternate state (Hughes, 1994). We therefore considered that the higher the functional redundancy, the less sensitive mangroves are to disturbances. 
Functional biodiversity indices, which include functional originality, richness, diversity and dispersion indices (FOri, FRic, FDiv, and FDis respectively) among others, are based on species traits values. We compiled the following traits values for each true mangrove species present in French territories, based on Duke's World Mangrove iD e-book Android Version 1.0 (Duke, 2014). To our knowledge, this is the only database that covers every species of mangrove in the world, with a common terminology of traits between species. Species list might need correction or updating, as we removed some species that were never confirmed on some territory.

We selected traits to account for their tolerance to salinity (tidal zone and estuarine position), their ability to attenuate wave energy (growth form and roots type), to oxygenate and stabilize the sediment (roots type), their productivity (leaf type and leaf size) and their reproductive strategy (flowering and fruiting) (Table S1 in Supplementary Materials). Final traits selected are the following:

- Tidal zone (high, mid, low), ordered.

- Estuarine position (downstream, intermediate, upstream), ordered

- Growth type (fern, palm, shrub, shrub-tree, tree), ordered.

- Roots (pneumatophores, below-ground, knee roots, aerial prop roots, sturdy props lenticellate, serpentine ribbon-like).

- Leaf type (simple, compound, pinnate), ordered.

- Leaf size (length in $\mathrm{cm}$ ), ordered.

- Inflorescence type (spike, capitulum, raceme, panicle, catkins, dichasia, solitary, absent, cyme, branching).

- Fruit (capsule, drupe, berry, nutlet, pod, carpel, legume).

- Release (spore, seeds, hybrid, propagule), ordered.

- Seed number (unknown, hybrid, solitary, numerous). 
- Germination (unknown, spore, hybrid, epigeal, hypogeal, viviparous, cryptoviviparous, embryo minute).

Given the high plasticity and adaptability of mangrove trees with changing environmental conditions (Vovides et al., 2014), some traits value certainly doesn't reflect the reality in some territories. Functional biodiversity indices should therefore be interpreted with caution, and be adjusted in the future with a French data base of mangroves traits per territory for instance. Ideally, mangroves trees traits database should be accompanied with other taxa traits databases, but to this date, no database exists for French overseas territories.

To calculate these functional biodiversity indices, following Maire et al. (2015) approach, we first computed a Principal Coordinates Analysis (PCoA) using Gower's metric on the matrix of these functional traits by species and retained the functional space showing the highest quality (the average error is less than $5 \%$ ) with the minimum number of dimensions. In our case, the functional space presenting the higher quality had seven dimensions for an average error of $4.7 \%$. We then computed these functional biodiversity indices (see Table S3 in Supplementary Materials) using the function multidimFD (Villéger et al., 2008) with the matrix representing mangroves species in this new functional space and the presence/absence matrix of mangroves species in each territory (Table S2 in Supplementary Materials).

Finally, we calculated a functional redundancy index FRed as $1-$ FOri, ranging from 0 to 1. Considering that the higher the functional redundancy, the less sensitive mangroves are, a functional sensitivity score of 1 was associated with $F R e d=1$, and a score of 5 was associated with FRed $=0$. All analyses were computed using the R ver. 3.6.1 statistical environment (R Development Core Team, 2019). 


\section{Adaptive capacity}

We considered the adaptive capacity of mangroves to be a function of their ability to cope with environmental changes and absorb disturbance, while maintaining their functions, thereby preventing the loss of critical ecosystem services (Folke et al., 2004). We assessed this adaptive capacity considering two parameters: mangrove functional diversity and existing level of protection (related to conservation measures in place). Indeed, functional diversity is expected to promote ecosystem resilience (Folke et al., 2004), consequently maintaining ecosystem functions and services in the face of environmental fluctuations and global environmental change (Bernhardt and Leslie, 2013). The functional richness FRic and Functional diversity FDiv, two of the functional biodiversity indices presented in the previous sub-section, can only be computed if the number of species is larger than the number of functional axes resulting from the PCoA, which was not the case here. Therefore, we used the functional dispersion FDis (Laliberté and Legendre, 2010) provided by the function multidimFD (Villéger et al., 2008; see the previous sub-section for more details) as a proxy of functional diversity for each territory (de Arruda Almeida et al., 2018). FDis is a multivariate measure of the dispersion of species in the functional multidimensional space and represents the mean distance of species to the centroid of the community. This functional diversity index accounts for both the volume of occupied functional space and the distribution of species within this space. Given the index ranges from 0 to 1 and assuming that the higher the functional dispersion, the higher the adaptive capacities of mangroves, a score of 1 was associated with $F D i s=1$ and a score of 5 was associated with FDis $=0$ (Fig. 1).

The level of protection was assessed through independent appraisal by experts from the French Tropical Wetlands Network, Conservatoire du Littoral, the Research Development Institute (IRD), universities and regional focal points in each overseas territory. The question asked to each expert was the following: considering the level of pressure on mangroves, is the level of protection sufficient in your territory? A score of 1 was assigned to territories where 
mangroves benefited from adequate regulatory protection and management, and a score of 5 was assigned to territories where mangroves severely lacked protective measures. Although one question certainly isn't enough to apprehend such a difficult and often subjective task, it was intended to do so because current indicators based on the surface areas of mangroves 'protected' and the surface areas of mangroves 'effectively managed' in French Overseas territories are not mature enough to represent the true need of mangroves protection, nor the true level of mangroves management. For instance, in Wallis and New Caledonia, traditional mangrove management is not represented yet.

\subsection{Coastal Protection (Wave attenuation, storm surge protection)}

Mangroves contribute to the control of erosion rates, regulate the hydrological cycle and water flow (including flood control and coastal protection), and provide wind protection (HainesYoung and Potschin, 2018). In this paper, we limited our assessment to the service of coastal protection against the physical impact of waves. As mangroves naturally develop in sheltered areas and are all protected to some extent by coral reefs, seagrass beds or mud banks, our evaluation concerns mostly high energetic waves observed during severe storms or extreme events whose energy and height have not been totally dampened by associated ecosystems such as coral reefs and seagrass beds. Depending on the along-shore variability of geomorphological settings, the service of coastal protection rendered by mangroves could, therefore, be relevant to protect both urbanized area and natural terrestrial habitats from tidal waves, wind waves, cyclonic swells, and tsunami.

We valued the service of coastal protection by considering the capacity of mangroves to attenuate wave height along a cross-shore transect (Shepard et al., 2011). First, the relationship between wave height attenuation rates and the cross-shore extent of mangroves that were extracted from a literature review was assessed using a linear mixed-effect model (LMM) with 
restricted maximum likelihood. We could only use ecosystem cross-shore extent (length from seaward edge to the upper reach of the tide) as an explanatory variable, as it was the only parameter consistently available throughout the literature review. Furthermore, to account for the natural variability and complexity in the geomorphic settings and wave characteristics, we only retained field experiments in our literature review, and we considered the origin of the data (i.e. the study id.) as a random effect to control for these factors. Analysis of the residuals did not reveal any violation of model assumptions of normality and homoscedasticity. Following recommendations of Bates et al. (2015), the effect of ecosystem cross-shore extent on the wave attenuation rate was then assessed through likelihood ratio test (LRT) between the fitted model and the corresponding null model, with a significance threshold of $p<0.05$. Finally, the goodnessof-fit of the LMM was evaluated by computing marginal and conditional $\mathrm{R}^{2}\left(R_{m}^{2}\right.$ and $\left.R_{c}^{2}\right)$ that correspond, respectively, to the proportion of variance explained by the fixed effect (i.e. the ecosystem cross-shore extent) and to the proportion of variance explained by both the fixed and the random effect (i.e. the ecosystem cross-shore extent and the origin of the data reflecting other environmental parameters). All analyses were computed using the R ver. 3.6.1 statistical environment (R Development Core Team, 2019). LMM was fitted with lmer() ('lme4' package, Bates et al., 2015), while LRT was computed with anova() ('stats' package, R Development Core Team, 2019) and marginal and conditional $\mathrm{R}^{2}$ were computed with r.squaredGLMM() ('MuMIn' package, Bartón, 2017).

Estimates of LMM of wave height attenuation rates are presented in Table 2, along with the results of the LRT against the corresponding null models. The cross-shore extent of mangroves significantly explained the proportion of wave height reduction $\left(\chi_{1}^{2}=37.523, p<0.001\right)$ following a logarithmic relationship (Fig. 3). In fact, mangroves cross-shore extent explained $52 \%$ of the variance observed in the wave attenuation factor $\left(R_{m}^{2}=0.525\right)$ with other environmental parameters explaining an extra $46 \%$ of the variance observed $\left(R_{c}^{2}=0.979\right)$. Those environmental parameters 
probably refer to geomorphic settings, spatio-temporal variability, bathymetry, incidence angle and energy of waves, currents, sediments type, mangrove tree species, etc.).

\section{Table 2}

Results from the Linear Mixed Model of the wave attenuation factor for mangroves and Likelihood Ratio Test with the null model ( $\mathrm{n}=21$ observations).

\begin{tabular}{crrrrrr}
\hline Mangroves & Estimate & Std. Error & $\boldsymbol{t}$ value & $\chi^{2}$ & Df & $\boldsymbol{p}$ \\
\hline Intercept & -55.387 & 7.628 & -7.261 & & & \\
Ln(Ecosystem depth) & 23.098 & 1.344 & 17.187 & 37.523 & 1 & $<0.001$ \\
\hline
\end{tabular}

Fig. 3. Wave height attenuation rate by mangrove cross-shore extent from a Linear Mixed Model (LMM). Dotted lined indicates the standard error of LMM's estimates.

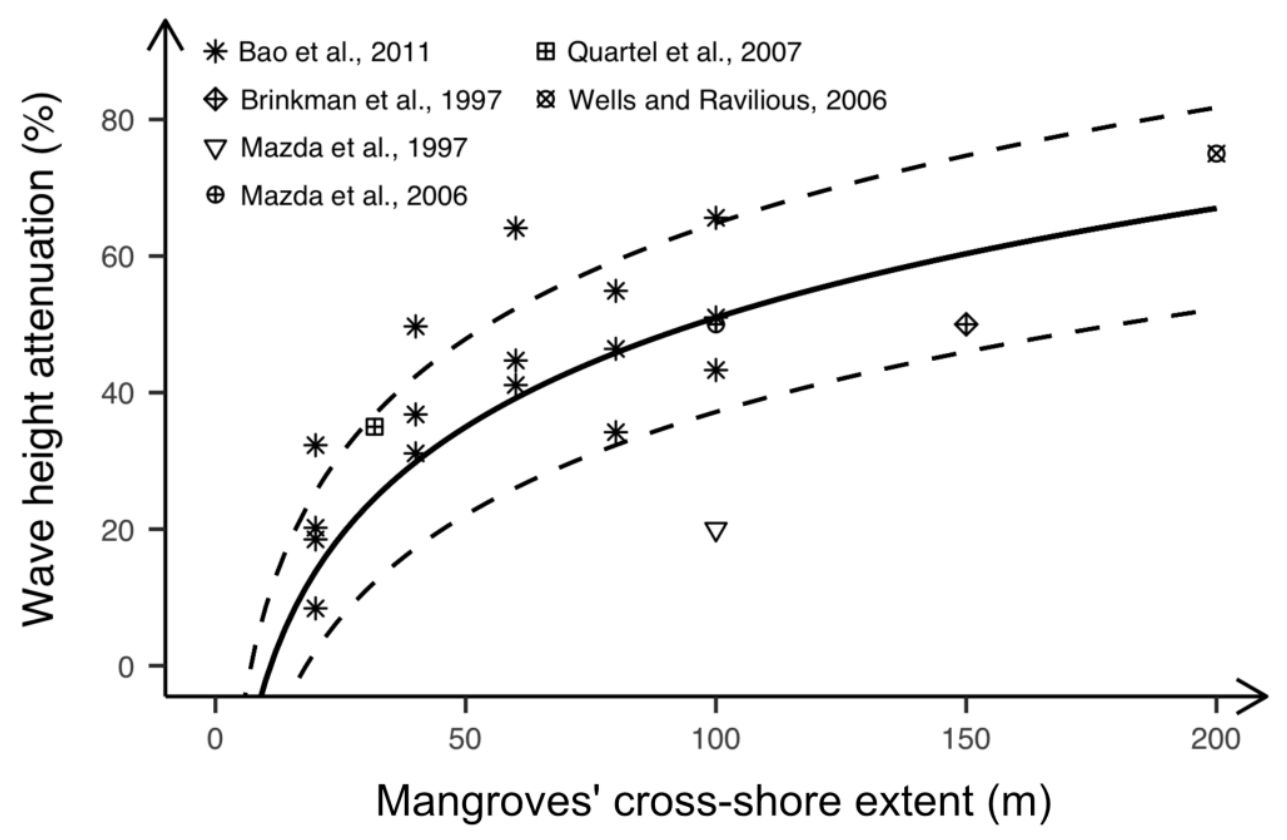

Wave attenuation data were collected from different regions with different environmental settings. Most data are from Vietnam, in the deltas of the Red River (Bao, 2011; Quartel et al., 2007), Tong King (Mazda et al. 1997) and Can Gio (Bao, 2011) where mangroves are sheltered 
from large intertidal mudflats and sand banks with mean wave height measured between $0.11 \mathrm{~m}$ and $1 \mathrm{~m}$ and wave period from 5 to 10 seconds. Wave attenuation from mangroves also came from Japan (Iriomote Island) and Australia (near Townsville) where riverine mangroves and marine fringing mangroves are sheltered respectively by coral reefs and intertidal sand banks, with wave heights ranging from $0.08 \mathrm{~m}$ to $0.6 \mathrm{~m}$ and wave period from 3.6 to 5.8 seconds in the Australian case studies (Brinkman et al. 1997; Wells and Ravilious, 2006).

Wave attenuation data from mangroves are missing in the first twenty meters, which causes a misleading origin for the negative ordinate. Consequently, in the case of mangroves for which the cross-shore extent is less than $20 \mathrm{~m}$, we assumed a $1 \%$ attenuation rate.

In a second step, for each French Overseas territory, we measured both the along-shore and cross-shore extent ( $L_{j}$ and $l_{i}$ respectively; Fig. 2 and 1) of each mangrove unit previously identified in terms of land artificialisation (see Fig. 2 and 1, and sub-section 'Exposure'). We then predicted the wave height attenuation rate for each mangrove unit based on the relationship we established between the wave height attenuation rate and the cross-shore extent for mangroves globally.

Finally, the value of the coastal protection service for each territory was calculated using the replacement (by different artificial structures) cost method, such as:

$$
C P=\sum_{i=1}^{n} W A_{i} \times L_{i} \times C_{R S} \times W
$$

with $C P$ representing the value of coastal protection service for mangrove in a territory $\left(€ \mathrm{yr}^{-1}\right) ; W A_{i}$ the wave attenuation rate for a unit with a land artificialisation score of $i(0-100 \%)$; $C_{R S}$ the cost of implementation of an artificial replacement structure that offers full (100\%) coastal protection $\left(€ \mathrm{~km}^{-1} \mathrm{yr}^{-1}\right) ; L_{i}$ the along-shore extent of mangrove unit $i(\mathrm{~km})$; and $W$ the weighting factor of the territory (proportion, 0.1-1.0). 
In most countries where natural protections (i.e. coral reefs, mangroves) have disappeared as a result of human-induced degradation, heavy and expensive artificial systems have been constructed to protect the coast (Cesar, 1996). Breakwaters, seawalls, rock fills and artificial reefs are four of the most commonly used artificial structures. The annual costs of these four artificial structures were estimated from a review of literature in other countries (Table S4 in Supplementary Materials) and adjusted for France Gross Domestic Product at Purchasing Power Parity (GDP PPP) Per capita as follows: 1) costs derived from the literature were converted in euros using yearly averaged exchange rates of the estimation year, 2) costs were adjusted to 2017 prices accounting for each country inflation rates (Campagne et al., 2015), and 3) costs were adjusted to France 2017 GDP PPP Per capita through models of costs according to study countries' 2017 GDP PPP Per capita. Accordingly, the annual costs of breakwaters, seawalls, rock fills and artificial reefs were estimated respectively at 552,226€ $\mathrm{km}^{-1} \quad \mathrm{yr}^{-1}, 946,121 € \mathrm{~km}^{-1} \mathrm{yr}^{-1}, 820,298 € \mathrm{~km}^{-1} \mathrm{yr}^{-1}$ and $357,899 € \mathrm{~km}^{-1} \mathrm{yr}^{-1}$ on average in 2017 in France for a GDP PPP Per capita of 38,978€.

\subsection{Carbon sequestration}

To estimate the service of carbon sequestration, we first determined the annual sequestration rate of mangroves for each territory through the net primary production $(\mathrm{NPP}=$ photosynthesis - respiration). We extracted NPP values from the Net Primary Production - NPP (MOD17A2/A3) products from the NASA Earth Observing System MODIS Land Algorithm for the year 2019 using the AppEEARS application (https://lpdaacsvc.cr.usgs.gov/appeears). NASA provides a regular global estimate of daily gross primary productivity (GPP) and annual net primary productivity (NPP) of the entire terrestrial earth surface at $500 \mathrm{~m}$ spatial resolution (Running et al., 2004; Zhao et al., 2005). The Primary Production products are designed to provide an accurate regular measure of the terrestrial vegetation growth. The derivation of a 
satellite estimate of terrestrial NPP has three theoretical components: (1) the idea that plant NPP is directly related to absorbed solar energy, (2) the theory that a connection exists between absorbed solar energy and satellite-derived spectral indices of vegetation, and (3) the assumption that there are biophysical reasons why the actual conversion efficiency of absorbed solar energy may be reduced below the theoretical potential value (but see https://modis.gsfc.nasa.gov/data/dataprod/mod17.php for further details).

To calculate the monetary value, we used the 2030 tutelary value (reference price of carbon set by a State for public/private investments) of $250 €$ per $\mathrm{tCO}_{2}$ given the evolution of objectives and techniques and observed delays in lowering the world's greenhouse gas emissions (France Stratégie, 2019). This new tutelary value of carbon gives a monetary value to public and private decarbonisation actions to achieve objectives aligned with the Paris Agreement. It represents the price of carbon necessary to efficiently guide investment, research and development choices in the context of a changing climate.

By making use of the tutelary value of carbon approach, we aim to value mangroves service as climate change mitigation providers. However, the blue carbon stock is partially offset by methane emissions, through the process of dissimilatory nitrate reduction into ammonium (DNRA), on average by $20 \%$ (Rosentreter et al., 2018). Consequently, we applied a methane emission offsetting coefficient $(M E)$ that corresponds to a $20 \%$ reduction in the climate mitigation value of carbon sequestration (Tanner et al., 2019).

We also compared carbon sequestration with anthropogenic carbon emissions (energy, industrial processes, agriculture, residential and tertiary, waste management, transport) per territory (CITEPA, 2019) to measure the offsetting due to blue carbon generated by mangroves.

The value of the carbon sequestration service for each territory was thus calculated as:

$$
C S=N P P \times(1-M E) \times A \times C_{C O 2}
$$


with $C S$ representing the value of carbon sequestration service for mangrove in a territory

$\left(€ \mathrm{yr}^{-1}\right) ; N P P$ the annual net primary production for the territory $\left(\mathrm{tCO} 2 \mathrm{eq} \mathrm{km}^{-2}\right.$ year $\left.^{-1}\right) ; M E$ methane emission offsetting coefficient; $A$ the total area of mangrove for the territory $\left(\mathrm{km}^{2}\right)$; and $C_{C O 2}$ the 2030 tutelary value of 1 ton of $\mathrm{CO}_{2}$ in France $\left(€ \mathrm{tCO}_{2} \mathrm{eq}^{-1}\right)$.

\subsection{Water purification (Nitrogen removal)}

Water purification by mangroves involves the uptake of nitrogen $(\mathrm{N})$ from terrestrial or coastal sources. Few mechanisms exist through which nitrogen $(\mathrm{N})$ can be removed; however, denitrification transforms biologically available $\mathrm{N}$ and releases it to the atmosphere as either dinitrogen $\left(\mathrm{N}_{2}\right)$, nitrous oxide $\left(\mathrm{N}_{2} \mathrm{O}\right)$ or ammonia $\left(\mathrm{NH}_{3}\right)$. Denitrification was found to be a dominant pathway for nitrogen loss in mangroves, with up to about $90 \%$ of that loss from anoxic sediments in a subtropical mangrove forest in China (Xiao et al., 2018). Xiao et al. (2018) also found that denitrification rates were higher in vegetated sediments $\left(5.01 \mathrm{nmol} \mathrm{g}^{-1} \mathrm{~d}^{-1}\right)$ than in unvegetated ones $\left(1.87 \mathrm{nmol} \mathrm{g}{ }^{-1} \mathrm{~d}^{-1}\right)$ which confirm the findings by Kristensen et al. (1998) in Thailand with denitrification rate of $0.6 \mathrm{~kg} \mathrm{~N} \mathrm{~km}^{-2} \mathrm{~d}^{-1}$ and $0.2 \mathrm{~kg} \mathrm{~N} \mathrm{~km}^{-2} \mathrm{~d}^{-1}$ respectively in vegetated and unvegetated sediments. This outcome confirms the need to adjust the production function according to the ecological state of mangroves and to develop appropriate ecological indicators to assess the service of water purification.

To estimate the service of water purification, we first conducted a literature review of the denitrification rates of mangroves. The value of the water purification service for each territory was then calculated using the replacement cost method, such as:

$$
W P=D \times A \times C_{N R} \times W
$$

with $W P$ representing the value of water purification service for mangroves in a territory $\left(€ \mathrm{yr}^{-1}\right)$; $D$ the average denitrification rate of mangroves according to the literature $\left(\mathrm{kgN} \mathrm{km}^{-2} \mathrm{year}^{-1}\right) ; A$ the total area of mangrove for the territory $\left(\mathrm{km}^{2}\right) ; C_{N R}$ the cost of nitrogen removal through 
wastewater treatment plants in France $\left(€ \mathrm{kgN}^{-1}\right)$; and $W$ the weighting factor of the territory (proportion, 0.1-1.0).

The average denitrification rate measured in mangroves sediments is $11.6 \mathrm{tN} \mathrm{km}^{-2} \mathrm{yr}^{-1}$ with a low value of $3.3 \mathrm{tN} \mathrm{km}{ }^{-2} \mathrm{yr}^{-1}$ and a high value of $17.2 \mathrm{tN} \mathrm{km}{ }^{-2} \mathrm{yr}^{-1}$ (see Table S5 in Supplementary Materials). The cost of nitrogen removal through wastewater treatment plants in France was determined using the average price paid by French consumers for water treated by wastewater treatment plants, expressed in $€ \mathrm{~m}^{-3}$ (see Table S6 in Supplementary Materials), and the average nitrogen load in the water at the entrance of wastewater treatment plants in France, expressed in $\mathrm{kgN} \mathrm{m}^{-3}$. The latter was estimated at $0.10 \pm 0.001 \mathrm{kgN} \mathrm{m}^{-3}$ and corresponds to the ratio between the maximum incoming charge (expressed in equivalent inhabitant $-\mathrm{EH}$ ), converted into $\mathrm{kgN}$, considering that $1 \mathrm{EH}=60 \mathrm{~g} \mathrm{BOD} 5=15 \mathrm{gN}$ day ${ }^{-1}$, and the daily inflow $\left(\mathrm{m}^{3}\right.$ day $\left.^{-1}\right)$ measured from all water treatment plants in France $(n=12,961)$ (MTES, 2018).

\subsection{Fish biomass production}

Mangroves are important food, breeding and nursery areas for many fish and shellfish of commercial interest (Roussel and Rivasseau, 2008). Fringes of mangroves are most regularly inundated and are therefore essential for fish biomass production (Trégarot et al., 2017). Furthermore, since the entire area contributes leaf detritus via the tidal exchange, which is recycled into the food chain, the entire mangrove area contributes to fish biomass production (Hutchison et al., 2014).

To estimate the average fish biomass, we selected studies using the same sampling methods, i.e. blocking nets, set up at the opening of mangrove creeks at high tide. The pioneering submerged front surface at high tide is estimated, whilst the amount of fish caught at low tide allows the estimate of fish biomass per unit area. The monetary value is often calculated based on the market

price of fish (Failler et al., 2010; Giry et al., 2017; Trégarot et al., 2017) and the catchable fish 
biomass (Thollot, 1992). In this study, we used the estimate of fish biomass production through fish farming instead, and accordingly valued the fish biomass production service through the replacement cost method as follow:

$$
F B P=B \times A \times C_{F B P} \times W
$$

with $F B P$ representing the value of the fish biomass production service $\left(€ \mathrm{yr}^{-1}\right) ; B$ the average annual biomass production of mangroves per unit area $\left(\mathrm{kg} \mathrm{km}^{-2} \mathrm{yr}^{-1}\right)$; $A$ the total area of mangroves for the territory $\left(\mathrm{km}^{2}\right) ; C_{F B P}$ the cost of producing one kilogram of fish through fish farming $\left(€ \mathrm{~kg}^{-1}\right)$ adjusted to France GDP PPP Per Capita 2017 (38,978 €); and $W$ the weighting factor of the territory (proportion, 0.1-1.0).

The average fish biomass observed in mangroves is $149 \pm 21 \mathrm{~kg} \mathrm{ha}^{-1}(\mathrm{n}=89)$ (see Table S7 in Supplementary Materials). The annual costs of producing $1 \mathrm{~kg}$ of fish through fish farming were estimated at $8.51 \pm 3.11 €$ for an exchange rate USD over EUR in 2017 at 1.129686 (Table S8 in Supplementary Materials).

\section{Results}

\subsection{Mapping, surface area of mangroves and level of artificialisation/urbanisation at} their vicinity in French overseas territories.

Mangroves of the French Overseas territories, not including French Polynesia, cover 87,733 ha in total. French Guiana has the highest cover with 53,106 ha. In the Lesser Antilles, Guadeloupe hosts the largest extent of mangroves (3,306 ha), followed by Martinique (1,856 ha), and to a much lesser extent, Saint-Martin (5.3 ha) and Saint-Barthelemy (4.6 ha), where mangroves are often located within inland lagoons. In the Indian Ocean, mangroves cover 623 ha in Mayotte and 626 ha in the Scattered Islands (Europa and Juan de Nova). In the Pacific Ocean, New-Caledonia has a mangrove extent of 28,173 ha, as for Wallis-and-Futuna, only the island of Wallis has mangroves (32.7 ha). In French Polynesia, introduced Rhizophora stylosa has 
colonised six islands, covering 40 ha in total. Fig. 4 shows the distribution of mangroves in each French overseas territory, including French Polynesia.

Fig. 4. Distribution of mangroves in French Overseas territories. For better visualization of the mangroves, the cross-shore extents have been exaggerated. Sources: Own realization; French Polynesia - Taureau (2019); world distribution of mangroves - Spalding et al. (2010).

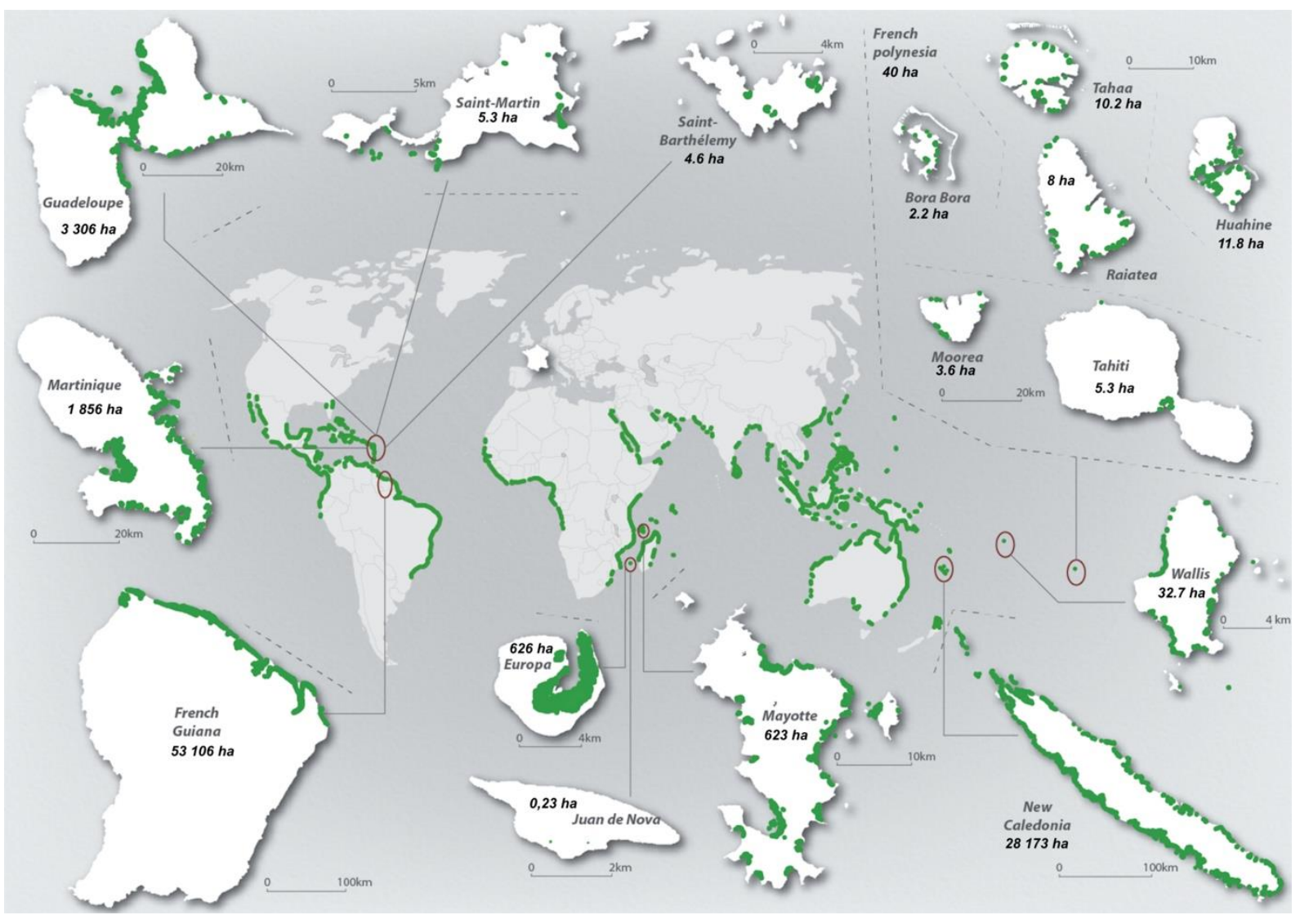

Land artificialisation behind the mangroves was characterised from Google Earth satellite imagery (Fig. 2), for all French Overseas territories, and is illustrated in Fig. 5.

Fig. 5. Relative proportion of land artificialisation in French Overseas territories, as the relative proportion of mangroves total alongshore extent (\%) per territory. 


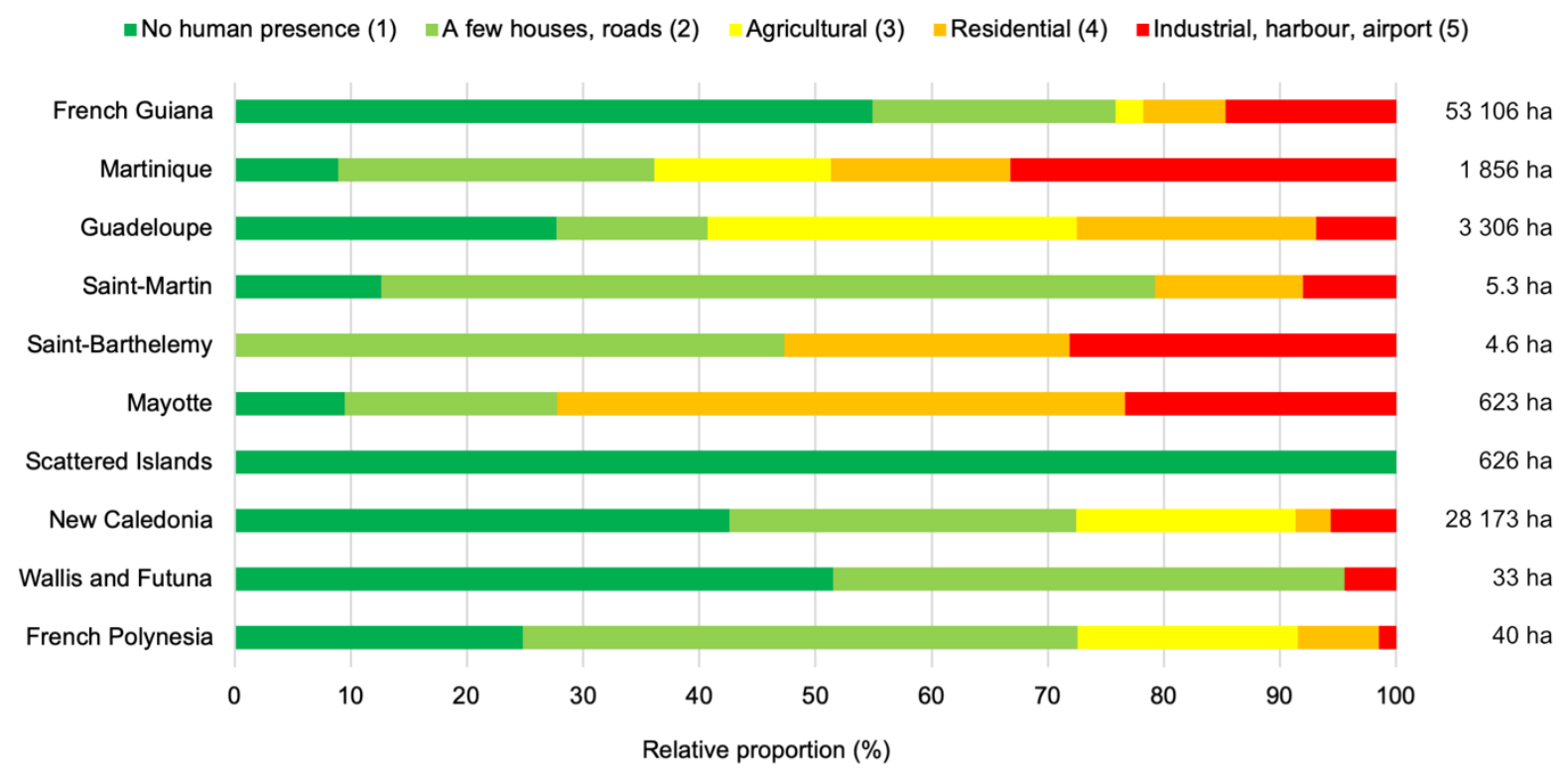

\subsection{Vulnerability assessment}

According to the different scores of exposure, sensitivity and adaptive capacity, the vulnerability assessment highlights a low vulnerability of mangroves in French Guiana, the Scattered Islands, New-Caledonia, and Wallis with a weighting factor of 0.8 , followed by Mayotte (0.7). Mangroves presenting the highest vulnerability are in the Lesser Antilles, with a weighting factor of 0.6 for Martinique and Guadeloupe, 0.5 for Saint-Barthelemy, and 0.4 for Saint-Martin. 


\section{Table 3}

Criteria for ranking mangrove vulnerability in French Overseas territories. Scores range from 1 to 5,5 being the most vulnerable category.

\begin{tabular}{|c|c|c|c|c|c|c|c|c|c|}
\hline Vulnerability criteria & FG & $\mathbf{G}$ & MQ & SM & SB & MY & SI & NC & WF \\
\hline \multicolumn{10}{|l|}{ Exposure components } \\
\hline Tidal range & 2 & 4 & 5 & 5 & 5 & 1 & 1 & 3 & 3 \\
\hline Precipitation regime & 2 & 3 & 3 & 3 & 3 & 2 & 2 & 1 & 2 \\
\hline Land artificialisation & 2 & 3 & 3 & 3 & 3 & 4 & 1 & 1 & 2 \\
\hline \multicolumn{10}{|l|}{ Sensitivity components } \\
\hline Mangrove condition & 1 & 3 & 3 & 5 & 3 & 3 & 2 & 2 & 2 \\
\hline Functional sensitivity & 3 & 3 & 2 & 3 & 3 & 2 & 3 & 3 & 2 \\
\hline \multicolumn{10}{|c|}{ Adaptive capacity components } \\
\hline Functional dispersion & 1 & 1 & 1 & 2 & 2 & 1 & 3 & 2 & 2 \\
\hline Mangrove protection & 2 & 3 & 3 & 4 & 2 & 3 & 1 & 3 & 2 \\
\hline \multicolumn{10}{|l|}{ Ranking } \\
\hline Vulnerability Rank & 13 & 20 & 20 & 25 & 21 & 16 & 13 & 15 & 15 \\
\hline Weighting factor $W$ & 0.8 & 0.6 & 0.6 & 0.4 & 0.5 & 0.7 & 0.8 & 0.8 & 0.8 \\
\hline
\end{tabular}

\subsection{Coastal protection}

From the wave height attenuation rate an, Table 4 shows coastal protection value per French Overseas territory, considering four types of artificial structures. 


\section{Table 4}

Economic value of the service of coastal protection provided by mangroves annually in the French Overseas territories expressed as mean [min-max] according to the cost of each artificial structure. The maximal total value for all territories corresponds to the value without applying the vulnerability index (weighting factor $=1$ ).

\begin{tabular}{|c|c|c|c|c|c|c|}
\hline $\begin{array}{l}\text { French } \\
\text { Overseas } \\
\text { territory }\end{array}$ & $\begin{array}{l}\text { Along- } \\
\text { shore } \\
\text { extent } L \\
(\mathbf{k m})\end{array}$ & $\begin{array}{l}\text { CP }\left(€ \text { year }^{-1}\right) \\
\text { Breakwaters }\end{array}$ & $\begin{array}{l}\text { CP }\left(€ \text { year }^{-1}\right) \\
\text { Seawalls }\end{array}$ & $\begin{array}{l}\text { CP }\left(€ \text { year }^{-1}\right) \\
\text { Rock Fills }\end{array}$ & $\begin{array}{l}\text { CP }\left(€ \text { year }^{-1}\right) \\
\text { Artificial } \\
\text { Reefs }\end{array}$ & $\begin{array}{l}\text { Mean Value } \\
\left(€ \text { year }^{-1}\right)\end{array}$ \\
\hline French Guiana & 344.60 & $\begin{array}{l}143,399,009 \\
{[135,291,070-} \\
148,306,220]\end{array}$ & $\begin{array}{l}245,683,325 \\
{[231,792,117-} \\
254,090,774]\end{array}$ & $\begin{array}{l}213,010,226 \\
{[200,966,391-} \\
220,299,580]\end{array}$ & $\begin{array}{l}92,937,185 \\
{[87,682,413-} \\
96,117,558]\end{array}$ & $\begin{array}{l}173,757,436 \\
{[87,682,413-} \\
254,090,774]\end{array}$ \\
\hline Martinique & 71.22 & $\begin{array}{l}15,211,631 \\
{[11,944,326-} \\
17,975,083]\end{array}$ & $\begin{array}{l}26,061,854 \\
{[20,464,031-} \\
30,796,434]\end{array}$ & $\begin{array}{l}22,595,923 \\
{[17,742,546-} \\
26,700,857]\end{array}$ & $\begin{array}{l}9,858,688 \\
{[7,741,142-} \\
11,649,687]\end{array}$ & $\begin{array}{l}18,432,024 \\
{[7,741,142-} \\
30,796,434]\end{array}$ \\
\hline Guadeloupe & 65.42 & $\begin{array}{l}17,617,252 \\
{[15,211,292-} \\
19,012,297]\end{array}$ & $\begin{array}{l}30,183,367 \\
{[26,061,273-} \\
32,573,478]\end{array}$ & $\begin{array}{l}26,169,321 \\
{[22,595,419-} \\
28,241,574]\end{array}$ & $\begin{array}{l}11,417,776 \\
{[9,858,469-} \\
12,321,908]\end{array}$ & $\begin{array}{l}21,346,929 \\
{[9,858,469-} \\
32,573,478]\end{array}$ \\
\hline Saint-Martin & 4.57 & $\begin{array}{l}340,510 \\
{[223,486-} \\
469,697]\end{array}$ & $\begin{array}{l}583,391 \\
{[382,896-} \\
804,724]\end{array}$ & $\begin{array}{l}505,807 \\
{[331,975-} \\
697,705]\end{array}$ & $\begin{array}{l}220,685 \\
{[144,842-} \\
304,411]\end{array}$ & $\begin{array}{l}412,598 \\
{[144,842-} \\
804,724]\end{array}$ \\
\hline Saint-Barthelemy & 3.80 & $\begin{array}{l}72,829 \\
{[32,260-} \\
119,045]\end{array}$ & $\begin{array}{l}124,776 \\
{[55,270-} \\
203,957]\end{array}$ & $\begin{array}{l}108,182 \\
{[47,920-} \\
176,833]\end{array}$ & $\begin{array}{l}47,200 \\
{[20,908-} \\
77,153]\end{array}$ & $\begin{array}{l}88,247 \\
{[39,089-} \\
144,247]\end{array}$ \\
\hline
\end{tabular}




\begin{tabular}{|c|c|c|c|c|c|c|}
\hline $\begin{array}{l}\text { French } \\
\text { Overseas } \\
\text { territory }\end{array}$ & $\begin{array}{l}\text { Along- } \\
\text { shore } \\
\text { extent } L \\
(\mathrm{~km})\end{array}$ & $\begin{array}{l}\text { CP }\left(€ \text { year }^{-1}\right) \\
\text { Breakwaters }\end{array}$ & $\begin{array}{l}\text { CP }\left(€ \text { year }^{-1}\right) \\
\text { Seawalls }\end{array}$ & $\begin{array}{l}\text { CP }\left(€ \text { year }^{-1}\right) \\
\text { Rock Fills }\end{array}$ & $\begin{array}{l}\text { CP }\left(€ \text { year }^{-1}\right) \\
\text { Artificial } \\
\text { Reefs }\end{array}$ & $\begin{array}{l}\text { Mean Value } \\
\left(€ \text { year }^{-1}\right)\end{array}$ \\
\hline Mayotte & 34.04 & $\begin{array}{l}7,993,462 \\
{[6,101,974-} \\
9,766,876]\end{array}$ & $\begin{array}{l}13,695,076 \\
{[10,454,419-} \\
16,733,438]\end{array}$ & $\begin{array}{l}11,873,786 \\
{[9,064,100-} \\
14,508,081]\end{array}$ & $\begin{array}{l}5,180,579 \\
{[3,954,702-} \\
6,329,932]\end{array}$ & $\begin{array}{l}9,685,726 \\
{[7,393,799-} \\
11,834,582]\end{array}$ \\
\hline Scattered Islands & 8.16 & $\begin{array}{l}3,584,646 \\
{[2,985,372-} \\
3,604,935]\end{array}$ & $\begin{array}{l}6,141,519 \\
{[5,114,793-} \\
6,176,279]\end{array}$ & $\begin{array}{l}5,324,767 \\
{[4,434,583-} \\
5,354,904]\end{array}$ & $\begin{array}{l}2,323,216 \\
{[1,934,826-} \\
2,336,365]\end{array}$ & $\begin{array}{l}4,343,537 \\
{[1,934,826-} \\
6,176,279]\end{array}$ \\
\hline New Caledonia & 555.83 & $\begin{array}{l}172,430,679 \\
{[138,952,505-} \\
198,811,697]\end{array}$ & $\begin{array}{l}295,422,840 \\
{[238,065,198-} \\
340,621,034]\end{array}$ & $\begin{array}{l}256,134,949 \\
{[206,405,224-} \\
295,322,296]\end{array}$ & $\begin{array}{l}111,752,668 \\
{[90,055,397-} \\
128,850,259]\end{array}$ & $\begin{array}{l}208,935,284 \\
{[168,369,581-} \\
240,901,321]\end{array}$ \\
\hline $\begin{array}{l}\text { Wallis and } \\
\text { Futuna }\end{array}$ & 6.65 & $\begin{array}{l}901,123 \\
{[540,839-} \\
1,270,383]\end{array}$ & $\begin{array}{l}1,543,879 \\
{[926,611-} \\
2,176,528]\end{array}$ & $\begin{array}{l}1,338,561 \\
{[803,382-} \\
1,887,074]\end{array}$ & $\begin{array}{l}584,019 \\
{[350,019-} \\
823,338]\end{array}$ & $\begin{array}{l}1,091,896 \\
{[655,337-} \\
1,539,331]\end{array}$ \\
\hline French Polynesia & 13.79 & $\begin{array}{l}1,533,065 \\
{[775,122-} \\
2,412,127]\end{array}$ & $\begin{array}{l}2,626,577 \\
{[1,328,004-} \\
4,132,661]\end{array}$ & $\begin{array}{l}2,277,272 \\
{[1,151,394-} \\
3,583,064]\end{array}$ & $\begin{array}{l}993,583 \\
{[502,358-} \\
1,563,305]\end{array}$ & $\begin{array}{l}1,857,624 \\
{[502,358-} \\
4,132,661]\end{array}$ \\
\hline $\begin{array}{l}\text { ALL } \\
\text { TERRITORIES }\end{array}$ & $1,108.05$ & $\begin{array}{l}363,084,206 \\
{[312,058,246-} \\
401,748,359]\end{array}$ & $\begin{array}{l}622,066,605 \\
{[534,644,610-} \\
688,309,307]\end{array}$ & $\begin{array}{l}539,338,795 \\
{[463,542,935-} \\
596,771,968]\end{array}$ & $\begin{array}{l}235,315,600 \\
{[202,245,574-} \\
260,373,916]\end{array}$ & $\begin{array}{l}439,951,302 \\
{[378,122,841-} \\
486,800,888]\end{array}$ \\
\hline $\begin{array}{l}\text { ALL } \\
\text { TERRITORIES } \\
\text { MAX }\end{array}$ & $1,108.05$ & $\begin{array}{l}469,058,355 \\
{[402,587,059-} \\
519,414,315]\end{array}$ & $\begin{array}{l}803,630,491 \\
{[689,746,238-} \\
889,904,586]\end{array}$ & $\begin{array}{l}696,756,741 \\
{[598,017,804-} \\
771,557,359]\end{array}$ & $\begin{array}{l}303,997,659 \\
{[260,917,479-} \\
336,633,457]\end{array}$ & $\begin{array}{l}568,360,811 \\
260,917,479- \\
889,904,586]\end{array}$ \\
\hline
\end{tabular}


Note that in Saint-Barthelemy, and partly in Saint-Martin, mangroves are located inland, around internal lagoons, and therefore do not directly protect coastal dwellings from waves and storm surges. In total, the mean annual value reaches 440 million euros per year for all French Overseas territories. The value would be 568 million euros per year if we did not consider the vulnerability of mangroves.

\subsection{Carbon sequestration}

On an annual basis, mangroves sequestration rate in French Overseas territories reaches on average $41.14 \mathrm{tCO}_{2} \mathrm{eq} \mathrm{ha}^{-1} \mathrm{yr}^{-1}$ from the NPP MODIS product. Table 5 shows the results of carbon sequestration in mangroves, carbon emissions in 2017 and the average annual value in euros considering the $20 \%$ offset from methane emissions. 


\section{Table 5}

Annual monetary value of the service of carbon sequestration by the mangroves of the French Overseas territories $\left(€\right.$ year $\left.^{-1}\right)$. The maximal total value for all territories corresponds to the value if mangroves were not vulnerable (Here the weighting factor $\left.=1 / W_{i}\right)$.

\begin{tabular}{|c|c|c|c|c|c|}
\hline $\begin{array}{l}\text { French Overseas } \\
\text { territory }\end{array}$ & $\begin{array}{l}\text { Net Primary } \\
\text { Production } \\
\left(\mathrm{tCO}_{2} \mathrm{eq} \mathrm{ha}^{-1}\right. \\
\left.\text { year }^{-1}\right)\end{array}$ & $\begin{array}{l}\text { Carbon sequestration } \\
\mathrm{tCO}_{2} \text { year }^{-1}\end{array}$ & $\begin{array}{l}\text { Emission in } 2017 \text { - } \\
\text { tCO }_{2} \text { year }^{-1} \text { (trend } \\
\text { since } 2015 \text { ) }\end{array}$ & $\begin{array}{l}\text { Offset } \\
(2017)\end{array}$ & Annual monetary value $\left(€\right.$ year $\left.^{-1}\right)$ \\
\hline French Guiana & $\begin{array}{r}56.89[42.57- \\
64.59]\end{array}$ & $\begin{array}{r}3,020,935[2,260,829- \\
3,430,223]\end{array}$ & $3,910,000(-4.24 \%)$ & $77.26 \%$ & $\begin{array}{r}604,186,962[452,165,726- \\
686,044,550]\end{array}$ \\
\hline Martinique & $\begin{array}{r}37.80[24.96- \\
50.65]\end{array}$ & $70,159[46,318-93,999]$ & $2,465,000(-0.51 \%)$ & $2.85 \%$ & $14,031,731[9,263,667-18,799,795]$ \\
\hline Guadeloupe & $\begin{array}{r}39.64[26.79- \\
52.11]\end{array}$ & $131,037[88,571-172,289]$ & $2,874,000(+0.65 \%)$ & $4.57 \%$ & $26,207,323[17,714,209-34,457,777]$ \\
\hline Saint-Martin & $\begin{array}{r}20.19[19.45- \\
20.92]\end{array}$ & $107[103-111]$ & & & $21,396[20,618-22,174]$ \\
\hline Saint-Barthelemy & $\begin{array}{r}29.36[27.53- \\
34.50]\end{array}$ & 135 [127-159] & & & $27,011[25,323-31,738]$ \\
\hline
\end{tabular}




\begin{tabular}{|c|c|c|c|c|c|}
\hline Mayotte & $\begin{array}{r}45.14[11.01- \\
65.69]\end{array}$ & $28,123[6,859-40,927]$ & $479,000(+8.15 \%)$ & $5.87 \%$ & $5,624,569[1,371,846-8,185,348]$ \\
\hline Scattered Islands & $\begin{array}{r}31.56[10.64- \\
53.95]\end{array}$ & $19,765[6,665-33,784]$ & NA & NA & $3,953,014[1,332,993-6,756,896]$ \\
\hline New Caledonia & $\begin{array}{r}50.28[5.14- \\
85.14]\end{array}$ & $\begin{array}{r}1,416,510[144,753- \\
2,398,762]\end{array}$ & $5,024,000(-1.56 \%)$ & $28.19 \%$ & $\begin{array}{r}283,302,053[28,950,575- \\
479,752,382]\end{array}$ \\
\hline Wallis and Futuna & $\begin{array}{r}46.24[42.57- \\
47.71]\end{array}$ & $1,512[1,392-1,560]$ & $27,000(+2.32 \%)$ & $5.60 \%$ & $302,423[278,421-312,023]$ \\
\hline French Polynesia & $\begin{array}{r}54.32[52.85- \\
56.52]\end{array}$ & $2,173[2,114-2,261]$ & $900,000(+1.24 \%)$ & $0.24 \%$ & $422,528[422,784-452,144]$ \\
\hline ALL TERR. & & $\begin{array}{r}4,690,455[2,557,731- \\
6,174,074]\end{array}$ & $\begin{array}{r}15,680,000(- \\
1.25 \%)\end{array}$ & $29.91 \%$ & $\begin{array}{r}938,091,011[511,546,163- \\
1,234,814,829]\end{array}$ \\
\hline $\begin{array}{l}\text { ALL TERR. } \\
\text { MAX }\end{array}$ & & $428,013 \pm 57,648$ & $\begin{array}{r}15,680,000(- \\
1.25 \%)\end{array}$ & $2.73 \%$ & $\begin{array}{r}1,190,322,795[650,857,527- \\
1,567,109,345]\end{array}$ \\
\hline
\end{tabular}


In total, the service of carbon sequestration reaches an annual estimated value of $938 \pm 427$ million euros. The value would be around 1,190 \pm 539 million euros if we considered the mangroves were not vulnerable to anthropogenic pressure and climate change. Mangroves in territories located in the Caribbean and Amazonia accounted for $69 \%$ of the total value, while mangroves in the Pacific and Indian Ocean territories account for $30 \%$ and $1 \%$ respectively. The sequestration of carbon by mangroves offsets $77 \%$ of the total emissions in French Guiana, 28\% in New Caledonia, and 30\% for all territories' carbon emissions. The trend of carbon emission since 1990 has been rising steadily for most territories, with an $85 \%$ increase on average (CITEPA, 2019). Since the adoption of the Paris Agreement in 2015, carbon emissions have slightly decreased for most territories. Still, they remain higher in 2017 for Mayotte $(+8.15 \%)$, Wallis and Futuna $(+2.32 \%)$, French Polynesia $(+1.24 \%)$ and Guadeloupe/Saint-Martin and Saint-Barthelemy combined (+0.65\%).

\subsection{Water purification}

Based on a literature review of the average denitrification rates in mangroves, the cost of removing $1 \mathrm{kgN}$ per territory, Table 6 presents the economic valuation of the water purification service per French overseas territory. 


\section{Table 6}

Water purification annual monetary value in the mangroves of the French Overseas territories $\left(€\right.$ year $\left.{ }^{-1}\right)$. The maximal total value for all territories corresponds to the value without applying the vulnerability index (weighting factor $=1$ ).

\begin{tabular}{|c|c|c|c|c|}
\hline $\begin{array}{l}\text { French Overseas } \\
\text { territory }\end{array}$ & Denitrification $\left(\mathrm{kgN}_{\mathrm{gear}}{ }^{-1}\right)$ & $\begin{array}{l}\text { Denitrification } \\
\text { carrying capacity/ } \\
\text { population }\end{array}$ & $\begin{array}{l}\text { Cost of } \\
\text { removing } 1 \\
\operatorname{kgN}(€)\end{array}$ & $\begin{array}{l}\text { Annual monetary value (€ year- } \\
\text { 1) }\end{array}$ \\
\hline French Guiana & $\begin{array}{r}4,928,237[1,401,998- \\
7,307,386]\end{array}$ & $335 \%$ & 13.0 & $\begin{array}{r}64,067,078[18,225,979- \\
94,996,013]\end{array}$ \\
\hline Martinique & $129,178[36,749-191,539]$ & $6.3 \%$ & 25.7 & $3,319,864[944,444-4,922,557]$ \\
\hline Guadeloupe & $230,098[65,459-341,179]$ & $10.8 \%$ & 20.0 & $4,601,952[1,309,176-6,823,584]$ \\
\hline Saint-Martin & $4,943[1,406-7,329]$ & $0.1 \%$ & 20.1 & $4,943[1,406-7,329]$ \\
\hline Saint-Barthelemy & $5,363[1,526-7,952]$ & $0.5 \%$ & 20.1 & $5,363[1,526-7,952]$ \\
\hline Mayotte & $50,588[14,391-75,009]$ & $3.7 \%$ & 24.0 & $1,214,102[345,391-1,800,221]$ \\
\hline Scattered Islands & $58,114[16,532-86,169]$ & $22,113.4 \%$ & 20.1 & $1,168,094[332,303-1,732,002]$ \\
\hline New Caledonia & $\begin{array}{r}2,614,454[743,767- \\
3,876,605]\end{array}$ & $175.9 \%$ & 13.1 & $\begin{array}{r}34,249,353[9,743,350- \\
50,783,523]\end{array}$ \\
\hline
\end{tabular}




\begin{tabular}{|c|c|c|c|c|}
\hline Wallis and Futuna & $3,035[863-4,500]$ & $4.8 \%$ & 19.9 & $60,388[17,179-89,540]$ \\
\hline French Polynesia & $4,640[1,320-6,880]$ & $0.3 \%$ & 13.2 & $61,248[17,424-90,816]$ \\
\hline ALL TERRITORIES & $\begin{array}{r}8,018,855[2,281,226- \\
11,890,027]\end{array}$ & $\mathbf{7 7 , 7 \%}$ & & $\begin{array}{r}108,752,385[30,938,179 \\
161,253,537]\end{array}$ \\
\hline $\begin{array}{ll}\text { ALL } & \text { TERRITORIES } \\
\text { MAX } & \end{array}$ & $\begin{array}{r}10,181,648[2,896,503- \\
15,096,927]\end{array}$ & $98.6 \%$ & & $\begin{array}{r}139,452,931[39,671,955- \\
206,775,036]\end{array}$ \\
\hline
\end{tabular}


We estimated the annual value of the service of water purification to be on average 109 million euros, which is 31 million less than if mangroves were not considered vulnerable. In term of nitrogen removal, if we consider the nitrogen waste per equivalent inhabitant (1 EH: $5.475 \mathrm{kgN}$ year $\left.^{-1}\right)$, we can estimate what would represent the presence of mangroves in terms of water treatment. Across all territories, the amount of nutrients treated by mangroves is equivalent to $77.7 \%$ of the total population's wastewater, and it would reach $98.6 \%$ if mangroves fully provided their function of water treatment.

\subsection{Fish biomass production}

Based on the mean fish biomass observed in mangroves and the annual cost of producing 1 $\mathrm{kg}$ of fish, Table 7 presents the annual monetary value of fish biomass production in mangroves of the French Overseas territories.

\section{Table 7}

Fish biomass production annual monetary value of mangroves in the French Overseas territories ( $€$ year $\left.{ }^{-1}\right)$. The maximal total value for all territories corresponds to the value without applying the vulnerability index (weighting factor $=1$ ).

\begin{tabular}{|c|c|c|}
\hline $\begin{array}{l}\text { French Overseas } \\
\text { territory }\end{array}$ & $\begin{array}{l}\text { Fish biomass production } \\
\mathrm{kg} \mathrm{yr}^{-1}(\text { mean } \pm \text { s.e })\end{array}$ & $\begin{array}{l}\text { Annual monetary value }\left(€ \text { year }^{-1}\right) \\
\text { expressed as mean [min-max] }\end{array}$ \\
\hline French Guiana & $6,344,270 \pm 895,967$ & $54,009,908[29,416,585-84,183,240]$ \\
\hline Martinique & $166,294 \pm 23,485$ & $1,415,693[771,060-2,206,588]$ \\
\hline Guadeloupe & $296,212 \pm 41,832$ & $2,521,703[1,373,450-3,930,485]$ \\
\hline Saint-Martin & $317 \pm 45$ & $2,695[1,468-4,201]$ \\
\hline Saint-Barthelemy & $343 \pm 49$ & $2,924[1,593-4,557]$ \\
\hline Mayotte & $65,123 \pm 9,197$ & $554,403[301,957-864,128]$ \\
\hline
\end{tabular}




\begin{tabular}{|l|r|r|}
\hline Scattered Islands & $74,812 \pm 10,565$ & $636,889[346,883-992,695]$ \\
\hline New Caledonia & $3,365,667 \pm 475,315$ & $28,652,528[15,605,646-44,659,632]$ \\
\hline Wallis and Futuna & $3,906 \pm 552$ & $33,257[18,113-51,836]$ \\
\hline French Polynesia & $5,973 \pm 844$ & $50,851[27,696-79,260]$ \\
\hline ALL & $\mathbf{1 0 , 3 2 2 , 9 1 7} \pm \mathbf{1 , 4 5 7 , 8 5 0}$ & $\mathbf{8 7 , 8 8 0 , 8 5 1}[\mathbf{4 7 , 8 6 4 , 4 5 0 - 1 3 6 , 9 7 6 , 6 2 3}]$ \\
TERRITORIES & & \\
\hline ALL TERR. MAX & $\mathbf{1 3 , 1 0 7 , 1 4 6} \pm \mathbf{1 , 8 5 1 , 0 5 1}$ & $\mathbf{1 1 1 , 5 8 3 , 4 9 6}[\mathbf{6 0 , 7 7 4 , 1 3 4 - 1 7 3 , 9 2 1 , 0 5 5}]$ \\
\hline
\end{tabular}

In the current vulnerability conditions, French mangroves produce annually $10,323 \pm 1,457$ tons of fish, that correspond to a monetary value of 89 million euros on average, that is $79 \%$ of the maximal monetary value if mangroves were considered in excellent condition.

\section{Discussion}

Assessing the value of ecosystem services for mangroves and possible future changes is important as it can facilitate dialogues between decision-makers and managers; recent examples have demonstrated that it can lead to concrete conservation actions. For instance, in Bonaire Marine Park (Netherlands Antilles), mangroves' contribution to water purification is recognised through payment for protection included in divers' entrance fees - a good example of payment for ecosystem services (PES) (Thur, 2010; Wunder, 2015).

Overall, the monetary valuation of regulation and support services provided by mangroves in French overseas territories represents on average 1.6 billion euros per year, $60 \%$ of which is carbon sequestration, $28 \%$ coastal protection, $7 \%$ water purification and $6 \%$ fish biomass production. However, the monetary value should always be interpreted with caution, and be 
considered within the local environmental context (ecological and social). For instance, a pristine mangrove without any human infrastructure to protect from storm surges or sea-level rise would have a higher monetary value when considering the production function, but lower socio-economic importance than a vulnerable mangrove protecting industrial and residential areas.

Considering the above, several conclusions can be drawn out from this valuation exercise: (1) coastal protection being one of the most critical services that mangroves provide, mangrove patches most important for coastal protection should be prioritised for conservation and restoration, (2) mangroves have real potential as blue carbon sinks, and more attention should be drawn to that potential as it could fund conservation action, (3) nutrient retention is an essential service provided by mangroves, but this service provision does not replace the need for wastewater treatment plants, (4) fish biomass production is particularly important for French Guiana and New-Caledonia, but the future of this service provision is difficult to envisage.

Broader management implications are then discussed, with the specific case of French Polynesia discussed separately.

\subsection{Coastal protection against waves and storm surges}

Coastal protection is one of the most important service provided by mangroves in French overseas territories, representing $28 \%$ of their overall monetary value and estimated to range between $202 \mathrm{M} €$ and $688 \mathrm{M} €$ on average. This value must be interpreted with care considering the limits of such evaluation. First, in our replacement cost approach, we used the total alongshore extent of mangroves per territory. Despite the fact that we adjusted the wave attenuation rate with the cross-shore extent and that we assigned a vulnerability index, the value might still be overestimated compared to the actual ecological and socio-economic stakes at risk. Moreover, adopting such coastal defense structures is simply, and often, unachievable and unjustified (particularly true in French Guiana and the Scattered Islands) with regard to local geomorphic 
settings, nearshore processes or biodiversity conservation/protection measures. With the damage avoided cost approach, Pascal et al. (2016) used the cost of damages to beachfront dwellings and the frequency of flooding events for the last 20 years or so. However, if there is no human infrastructure to protect, mangrove is worth nothing in terms of coastal protection, which can be a very limiting approach too with regard to the value of dwellings (house vs. home), or the presence of coastal sensitive habitats and fauna.

Secondly, it must be acknowledged that this service is probably one of the most complex to assess due to spatio-temporal variability of waves, currents, sediment supply, geomorphic settings, data at appropriate resolution. For instance, wave direction and incidence angle for each mangrove unit were not considered for the cross-shore extent measurement; other ecosystems like coral reefs, seagrass beds and mud banks contribute to the dampening of wave and to the loading of sediment on the coast (Anthony et al., 2010; Christianen et al., 2013; Ferrario et al., 2014). The connectivity of those ecosystems and their cumulative attenuation of wave height along the shoreline, could shed light on their respective wave attenuation capacity. The more parameters we include, the more processes come into models. The availability of such specific data is a major constraint though across the French Overseas territories. Furthermore, our wave attenuation model relies on a few field studies that did not cover the Caribbean, Amazonia, nor the Indian Ocean where different mangrove species are found. However, data were collected in Vietnam, Japan, or Australia from deltaic, riverine, and marine fringing mangroves, representative of different geomorphic contexts, associated with large mud banks or coral reefs, as found in most of the French Overseas territories. Further field studies are still required to assess wave attenuation rates by mangroves according to the most prevailing geomorphic settings, mangrove forests' structures, and waves height and period. Offshore wave energy can be computed for all the French Overseas territories from wave data (i.e. wave height and period) found on web-platforms such as Marine Copernicus Service (see Table S1). However, wave conditions at the shorefront of mangroves are 
less energetic after being attenuated by adjacent ecosystems and the $1 / 12^{\circ}$ i.e. $9 \mathrm{~km}$ spatial resolution of wave data found on Marine Copernicus Service is thus not exploitable for small French Overseas territories if we focused on mangroves. On the other hand, it can still be appropriate for large territories such as New-Caledonia, where the distance between the external barrier reef and mangroves can be larger than $10 \mathrm{~km}$ (see Figure S3).

In the Lesser Antilles (Guadeloupe, Martinique, Saint Martin and Saint Barthelemy) where population densities are high, and coastal infrastructure is dense, coastal protection services reach an annual value ranging from $22 \mathrm{M} €$ to $57 \mathrm{M} €$, depending on the type of infrastructure located behind mangroves. In Martinique, we assessed the service ranging from 10 to $26 \mathrm{M} \mathrm{yr}^{-1}$, which is similar to the values of $16 \mathrm{M} €$ and 16.6 M€ estimated by Failler et al. (2010) and Giry et al. (2017) who both used the benefit transfer methods. The coastal protection service provided by mangroves in the French West Indies is therefore highly relevant, but mangroves do not have much space to move inland, meaning they might become "trapped" when sea level rises. In French Guiana, land artificialisation behind mangroves is low - only $45 \%$ of all mangroves directly protect human infrastructures in this territory - so mangroves are less vulnerable to coastal squeeze, as in the French West Indies. But this also means that the coastal protection service provided by mangroves in French Guiana are not as essential as in the French West Indies. Furthermore, the coastal protection service is in fact mostly offered by the Amazon sediment supply and the presence of large mud banks (Anthony et al., 2010 and references within). Further studies on coastal hydrodynamics (currents and waves) and morphodynamics (sediment transports and supply, bathymetry) are required at finer scale to assess wave energy and incidence angle at the shorefront of mangroves. Furthermore, mangroves face exceptional spatio-temporal dynamics due to intense coastal hydrosedimentary processes (Walcker et al., 2016). Any point on the coast experiences alternating periods of rapid and extensive mangrove progradation or erosion, which is observable on a monthly basis. Sediment inputs is a critical parameter for mangroves to be able to 
adapt from sea-level rise and the variability in sediment loads is crucial for examining mangrove adaptability thresholds. The assessment of coastal protection in French Guiana is to be interpreted with the utmost caution. Although no replacement structure (artificial reefs, breakwater) can realistically be implemented in such environment the replacement cost approach makes it possible to assign a monetary value, for every territory.

Similarly, in the Pacific region (New-Caledonia, Wallis), only $57 \%$ and $48 \%$ of the mangroves' alongshore extent directly protect human infrastructure, meaning they are both less vulnerable and less 'useful' to humans for coastal protection there. In the Indian Ocean, the low topography and low sediment supply in the Scattered Islands make mangroves vulnerable to rising sea levels, however since these islands are uninhabited, the service of coastal protection to people is almost non-existent. Conversely in Mayotte, we estimated coastal protection monetary value to

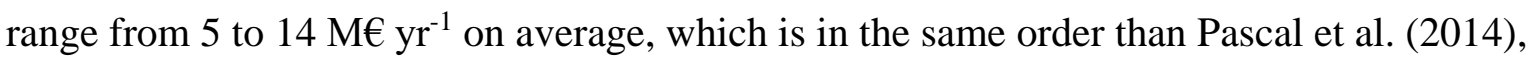
estimated at 10.5 $\mathrm{M} \mathrm{yr}^{-1}$ using the avoided damages cost approach. Trégarot et al. (2017) considered the value of coastal protection by mangroves in Mayotte as an option value (4.2 ${\mathrm{M} € \mathrm{yr}^{-}}^{-}$ 1 , since the double barrier reef and the fringing reef provided most of the wave attenuation function. Mangroves' coastal protection service is nevertheless important through other functions like shore stabilisation and sediment accretion, both crucial in the face of sea-level rise. Mayotte could be a particularly interesting case study, since the earthquake swarm episode between May 2018 and fall 2019 has led to a drop (subsidence) of the coast, up to $16 \mathrm{~cm}$ in some locations (REVOSIMA, 2019). This is all the more a problem for mangroves than land use and land conversion reduce mangroves' ability to retreat inland, and the island's topography, with $63 \%$ of Grande-Terre characterized by slopes steeper than $15 \%$, prevent any possible retreat. They extend over a narrow coastal strip and are faced with increasing anthropogenic pressure from land, with rear mangroves classified as critically endangered (CR) (IUCN French Committee, 2017). 


\subsection{Mangroves are potential blue carbon sinks}

The service of carbon sequestration provided by mangroves is the most important in French overseas territories, representing $60 \%$ of their overall monetary value (938 M€ year ${ }^{-1}$ ). For this service too, results should be interpreted with care. While the use of the appEEARS tool from NASA appears like a great alternative to traditional valuation methods, only simple geometries can be processed by the tool, and we had to simplify the geometries to obtain NPP on our study areas (see Figure S2 in the Supplementary Materials for an example). Given the $500 \mathrm{~m}$ spatial resolution of NPP products provided by MODIS, and the reduced extent of mangrove patches on most of the sites of the study, the estimates of NPP we use here have to be considered with caution. Indeed, in vast territories such as French Guyana, Martinique, Guadeloupe or New Caledonia, mangrove patches are large enough to be sure that the remotely-sensed NPP at $500 \mathrm{~m}$ resolution is representative of the ecosystem status. However, on smaller islands, pixels, where mangrove is present, are strongly contaminated by other types of vegetation, and the NPP only provides a rough estimate of the actual productivity of mangrove.

Since vast territories account for more than $98 \%$ of total French mangroves areas, our carbon sequestration estimates at the national scale, should not be impacted by the low resolution of MODIS NPP products. The amount of carbon sequestered annually represents the amount of carbon equivalent emitted by all territories' manufacturing industry, residential, tertiary, agriculture and forestry sectors combined. It represents $30 \%$ of the total emissions of $\mathrm{CO}_{2}$ of all territories. Even though mangroves are among the most effective ecosystems in sequestering atmospheric carbon, together with saltmarshes and seagrass beds (Taillardat et al., 2018; Cragg et al., 2020), complementary efforts are needed to reach carbon neutrality. Starting by reducing carbon emission from the transport (38\%), energy (35\%) and manufacturing industries (25\%) sectors, and implementing further conservation measures towards natural carbon sinks like other marine ecosystems and terrestrial forests. Now, PES schemes such as 'Reducing Emissions from Deforestation and Degradation' (REDD+) incentivize conservation through 'avoided 
deforestation', with a service buyer paying a service provider to store carbon that would otherwise be emitted due to land cover change. Payments for avoided deforestation are frequent in terrestrial forest conservation and are rapidly gaining traction in mangrove research and policymaking under the term 'blue carbon' (Mcleod et al., 2011; Sutton-Grier and Moore, 2016), with initiatives such as the International Blue Carbon Initiative, or the International Blue Carbon Partnership between Australia and Indonesia being created. This could gain even more traction if the carbon soil, and its variability across depth, space and age of mangroves, were accounted into the PES scheme REDD+ (Cragg et al., 2020; Walcker et al., 2018). Mangroves could then play a real carbon sink role for France's climate policies and strategies, including blue carbon schemes which could fund conservation and restoration efforts throughout French territories (Donato et al., 2011; Locatelli et al., 2014).

In this paper, we used the rate of carbon sequestration, which can be evaluated on an annual basis, unlike the carbon stock present in soils and biomass, on average $885 \mathrm{Mg} \mathrm{C}^{-\mathrm{ha}^{-1}}$ or $3239 \mathrm{t} \mathrm{CO}_{2} \mathrm{eq} \mathrm{ha}^{-1}$ (Kauffman and Bhomia, 2017). The level of carbon storage in the soil is reached over a long-timescale through the process of necromass and plant litter decomposition, followed by the process of burial into anoxic sediment where organic carbon breaks down very slowly (Cragg et al., 2020). However, the stock of carbon can be recirculated to the atmosphere if the mangroves are destroyed. If we consider that the total carbon stock of one hectare of mangrove, including the first meter of sediment, is released in the atmosphere following the reconversion of the territory (Hamilton and Friess, 2018), this represents 3,239 $\mathrm{tCO}_{2} \mathrm{eq}$, worth $809,750 € \mathrm{ha}^{-1}$. Consequently, the land conversion of one hectare of mangroves would represent a societal cost of $845,000 € \mathrm{ha}^{-1}$ for blue carbon over a generation (stock of carbon soils and biomass + annual sequestration of carbon for 30 years). 


\subsection{Water purification is an essential service but does not replace the need for wastewater treatment plants}

With a growing population, land-use changes, urbanisation and deforestation, runoffs constitute a significant stressor to coastal ecosystems. The service of nutrient filtration such as nitrogen removal provided by mangroves is essential, as it is estimated that they treat the equivalent of $77.7 \%$ of all French overseas territories' wastewater, for an annual monetary value of 109 million euros in total.

Similarly to coastal protection, the value of this service, or its relative importance, depends on the proximity of mangroves to dwellings, and more generally, to population density and activities. Therefore, the service of nutrient filtration is more pressing in densely populated territories such as Martinique or Mayotte $\left(1,789 € \mathrm{ha}^{-1} \mathrm{yr}^{-1}\right.$ and 1,949€ ha- $\mathrm{yr}^{-1}$ respectively), where water quality is essential for associated ecosystems (seagrass and coral reefs). This is not the case in French Guiana, where low population density and the absence of seagrass beds and coral reefs, due to naturally turbid waters, lower the importance of this service. However, even in the absence of human population, the function of nutrient cycling is essential to mangroves' productivity, which contributes to the provision of all other services and should therefore not be ignored. Another important consideration is the fact that the nutrient retention function by mangroves is not only beneficial to coastal water quality; it is also useful for agriculture. According to Hussain et al. (2008), it is estimated that one hectare of mangroves contains additional nutrients worth US\$232.49, and we estimated from satellite imagery that $32 \%$ of mangroves are currently adjoining agricultural fields in Guadeloupe, 19\% in New-Caledonia and $15 \%$ in Martinique. Adjacent mangroves then help in the removal of nitrogen from agricultural runoffs that wastewater treatment plants cannot deal with. We would like to emphasise; however, that mangroves do not replace the need for wastewater treatment plants, because poor water quality negatively impacts their functioning (Herteman, 2010). 
In any case, from a management point of view, it could be interesting to monitor parameters linked to this nutrient filtration service, such as vegetation density, soil salinity (Wang et al., 2018) and presence of crabs (Herteman, 2010) which all influence nitrification and denitrification processes. In addition to the removal of nitrogen from mangroves sediments by denitrification, other pathways could be included, namely the uptake of inorganic nitrogen by mangroves and anaerobic ammonium oxidation (anammox), that could remove about $10 \%$ of the nitrogen (Adame et al., 2019).

\subsection{Fish biomass production is particularly important for French Guiana and New}

\section{Caledonia, but the future of this service provision is difficult to envisage.}

Fish biomass production provided by mangroves in French territories were estimated at $10.3 \pm 1.5$ million $\mathrm{kg}$ year ${ }^{-1}$, worth 88 million euros annually on average for all territories. French Guiana is by far the territory where this service is the most valuable with 54 million $€$ year ${ }^{-1}$. However, the value would be significantly higher if we considered crustaceans since they use mangroves as an important nursery habitat (Diop et al., 2019). In French Guiana, shrimp fishery represents the third export sector of the territory. In New Caledonia, where fish biomass production service value is also high $\left(29\right.$ million $€$ year $\left.^{-1}\right)$, with 250 different fish species recorded in mangroves (Thollot, 1992), the number of invertebrate's species is likely to be considerable, with some species representing important food resources (e.g. mud crab Scylla serrata). In any case, more than the surface or density of mangroves, functional traits of mangroves trees seem to influence fish assemblages. For instance, Laguncularia spp. provides a more diverse array of conditions and generates a large amount of litterfall, while Avicennia germinans has the highest leaf decomposition rate, contributing to high productivity and high fish biomass. However, the link between mangroves community structure and fish biomass is not completely clear, and further studies are needed to find the right indicators for this service, noting that fish assemblages 
are also linked to anthropogenic impacts (López-Rasgado et al., 2016). It is worth noting that mangroves increase fisheries yields (Aburto-Oropeza et al., 2008) and contribute into inshore fisheries on associated ecosystems, such as coral reefs, through the function of nursery, and the outwelling of detritus (Hutchison et al., 2014; Mumby et al., 2004). Therefore, we need to have a better understanding of the effects of anthropogenic stressors and climate change on mangrove's functional ecology to predict their impacts (magnitude and direction of changes) on the associated fauna, which will ultimately affect most ecosystem services, including fish biomass production.

\subsection{Implications for management}

A range of legislative and regulatory tools exist to protect mangroves at different levels, from international conventions (Convention on Wetlands of international importance known as the Ramsar Convention, Convention on Biological Diversity, etc.), European laws (Water Framework Directive), and a plethora of national regulatory tools which differ from one territory to another. Territories with a less independent status (Overseas Regions or ORs in the European jargon) such as Guadeloupe, Martinique, French Guiana or Mayotte use French-specific protection tools such as national or regional natural reserves, national parks, marine parks or biotope protection regulations. In contrast, more independent territories such as Saint-Barthelemy, New-Caledonia or Wallis-and-Futuna have adopted their own mangrove protection regulations. An important conservation tool is the ability, for a State agency, named 'Conservatoire du Littoral', to purchase parcels of mangroves with a habitat protection objective in Overseas Regions. To date, a large majority (over $80 \%$ ) of mangroves in Martinique, Guadeloupe and Mayotte belongs to this Agency, which also owns over half of mangroves in French Guiana. However, mangroves continue to be threatened, due to limited financial, human and police means. This is illustrated by recently released results of two national indicators for French mangroves: ‘\% of mangroves that are under legal protection' on the one hand, and ' $\%$ of mangroves that are 
effectively managed' on the other (Pôle Relais Zones Humides Tropicales). First results indeed indicate that $70.6 \%$ of mangroves are under legal protection, but only $25.2 \%$ are effectively managed. A mapping protocol based on the exploitation of Sentinel-2 data via Google Earth Engine makes it possible to quantify future changes in mangroves distribution - particularly in French Guiana - and consequent changes in the provision of ecosystem services.

Although the above surface-based indicators provide a good overview of mangrove protection efforts in French overseas territories, they do not provide information on ecosystem services gain or loss. The relevance of developing ecosystem health indicators is often questioned because of their cost, which may prevent effective use by managers in the long-term. However, indicators that are too simplistic fail to represent the complexity of biological, ecological, and biogeochemical processes and they might not provide enough information to detect disturbances before it is too late (Loiseau and Gaertner, 2015). The development of ecological indicators should, therefore, be driven by the need to monitor both changes in ecosystem condition, and changes in the provision of services. Our study shows that traits such as tree density, tree height, and stem diameter are relevant morphological traits to monitor coastal protection whilst net productivity, leaf surface, and tree height are most suited for assessing carbon sequestration, along with the hydroperiod and soil characteristics (Sasmito et al., 2020). However, ecosystem functioning is not only based on tree diversity but also on mangrove macrobenthos (e.g. crabs as ecosystem engineers), molluscs, microorganisms (Cragg et al., 2020; Kristensen, 2008; Lee, 2008). Mangrove's macro- and meiobenthos are yet to be fully documented in French Overseas territories. Monitoring functional traits from trees and other taxa could, therefore, make sense in the frame of ecosystem services provisioning, and the French mangrove monitoring network (ROM) - which released a mobile application allowing to signal disturbances in mangroves in November 2019 - should aim at integrating these traits, through functional biodiversity indices 
and production functions, into national monitoring efforts. This, combined with the mobile app, could enhance managers' capacity to detect environmental changes and react on time.

\subsection{The specific case of introduced mangroves in French Polynesia}

The mangrove species Rhizophora stylosa was introduced to French Polynesia in the 1930s and has since colonized six islands (Moorea, Tahiti, Huahine, Raiatea, Tahaa, and Bora Bora), covering a surface area of 40 ha (Taureau, 2019) and potentially replacing local coastal ecosystems such as Paspalum vaginatum-dominated saltmarshes (Florence et al., 2013; Taureau, 2019). After 90 years of presence, uncertainty remains regarding 1) the exact threat or disservice mangroves in French Polynesia pose to the environment and local communities versus 2) ecosystem services they might provide, as highlighted in parts of the world where they occur naturally. In the French West Indies, a similar case exists with the phanerogam species Halophila stipulacea (Maréchal et al., 2013). Despite out-competing native phanerogam species, $H$. stipulacea still provides services such as carbon sequestration, coastal waters purification, habitat provision for important marine fishing resources, and shore erosion mitigation - similarly to local phanerogam species. As a consequence, this seagrass species has not been controlled.

Assessing the economic benefits of invasive species is ethically and scientifically disturbing. Still, when it comes to foundation species like mangroves, seagrass, or saltmarshes, potential economic benefits are hard to ignore, and the eradication of a productive ecosystem might be seen as counterproductive. We made the decision to include French Polynesian mangroves in this economic valuation study. However, these results should not be a motive for new plantation, which is forbidden since 1982, nor the introduction of $R$. stylosa on other islands of French Polynesia, even if mangroves could provide more benefits than the local species $P$. vaginatum (Ramus et al., 2017). Indeed, in order to make the most effective management action, further studies should be conducted to assess current and potential future the environmental and 
economic disservices (Vaz et al., 2017) and compare them to services provided by $R$. stylosa In French Polynesia, to then perform a cost/benefit analysis of mangroves eradication or control vs inaction or even planting, which is legally banned in French Polynesia at present.

\section{Conclusion}

We showed that mangroves provide essential ecosystem services in French Overseas territories, and contribute to the good functioning of coral reefs and seagrass beds. Money-wise, the service of carbon sequestration has the highest value and directly mitigates climate change through its feedbacks on atmospheric carbon concentration. The vulnerability index used here is a first step in adjusting mangroves production functions in French overseas territories, and lots of other parameters could be included (Ellison, 2015). The next step could be to consider all activities occurring in catchments, and not only the ones occurring at the immediate vicinity of the mangroves. Another research avenue could be to include other taxa in the assessment of mangroves' vulnerability. The IUCN Red List assessment of mangroves in Mayotte (IUCN French Committee, 2017) was an excellent initiative for assessing the vulnerability of mangroves in this territory, where mangroves are facing a steep rate of population growth and economic activities. This approach should be extended to all other territories, for which socio-economic pressures are still high, and the ongoing degradation of mangroves constitute a threat both for the local economy and the environment - starting with the French West Indies.

This study is the first assessment of mangroves' ecosystem services at the French national scale, with conclusions that can be directly useful to managers and decision-makers. This paper isn't a global framework for monetary valuation of mangroves in France but is rather a starting point for more detailed, territory-specific valuation. Differences between territories have been underlined through the vulnerability index, which considers some of the territories' specificities in 
the valuation of ecosystem services. However, the exercise of mangrove services valuation is very difficult. It must be rooted as far as possible in a deep understanding of coastal processes and the acknowledgement of their variability at all - spatial and temporal - scales of observation. It is important to emphasize that, while mangroves in French overseas territories benefit from international, European, national and local regulatory measures, these measures remain insufficiently funded to be properly and efficiently implemented. With an increasing emphasis being currently placed on the value of ecosystem services provided by mangroves to face climate change, a serviced-based approach to conservation would plead for increased national investment into their protection.

\section{Acknowledgements}

The authors would like to thank all the experts contributing to the scoring of mangroves protection and for the interesting exchanges about mangroves conservation issues that came along. The authors are thankful to the anonymous reviewers for their careful reading of the manuscript and their many insightful comments and suggestions.

\section{Funding sources}

This research did not receive any specific grant from funding agencies in the public, commercial, or not-for-profit sectors.

\section{Declaration of interests}

The authors declare that they have no known competing financial interests or personal relationships that could have appeared to influence the work reported in this paper.

\section{References}


Ablain, M., Legeais, J., Prandi, P., Marcos, M., Fenoglio-Marc, L., Dieng, H., Benveniste, J., \& Cazenave, A. (2017). Satellite altimetry-based sea level at global and regional scales. In A. Cazenave, N. Champollion, F. Paul, \& J. Benveniste (Eds.), Integrative study of the mean sea level and its components (Vol. 58, pp. 9-33): Springer, Cham.

Aburto-Oropeza, O., Ezcurra, E., Danemann, G., Valdez, V., Murray, J., \& Sala, E. (2008). Mangroves in the Gulf of California increase fishery yields. Proceedings of the national academy of sciences, 105(30), 10456-10459.

Adame, M. F., Roberts, M. E., Hamilton, D. P., Ndehedehe, C. E., Reis, V., Lu, J., Griffiths, M., Curwen, G., \& Ronan, M. (2019). Tropical coastal wetlands ameliorate nitrogen export during floods. Frontiers in Marine Science, 6, 671. doi:10.3389/fmars.2019.00671

Alatorre, L. C., Sánchez-Andrés, R., Cirujano, S., Beguería, S., \& Sánchez-Carrillo, S. (2011). Identification of mangrove areas by remote sensing: The ROC curve technique applied to the northwestern Mexico coastal zone using Landsat imagery. Remote Sensing, 3(8), 1568-1583.

Alongi, D. M. (2008). Mangrove forests: resilience, protection from tsunamis, and responses to global climate change. Estuarine, coastal and shelf science, 76(1), 1-13.

Anthony, E. J., Gardel, A., Gratiot, N., Proisy, C., Allison, M. A., Dolique, F., \& Fromard, F. (2010). The Amazon-influenced muddy coast of South America: A review of mud-bank-shoreline interactions. Earth-Science Reviews, 103(3-4), 99-121.

Bartón, K. (2017). MuMIn: Multi-Model Inference. R package version 1.40.0. https://CRAN.Rproject.org/package $=$ MuMIn

Bates, D., Maechler, M., Bolker, B., \& Walker, S. (2015). Fitting Linear Mixed-Effects Models Using lme4. Journal of Statistical Software, 67, 1-48. doi:10.18637/jss.v067.i01

Bernhardt, J. R., \& Leslie, H. M. (2013). Resilience to climate change in coastal marine ecosystems. Annual Review of Marine Science, 5, 371-392.

Brinkman, R. M., Massel, S. R., Ridd, P. V. \& Furakawa, K. (1997). Surface wave attenuation in mangrove forests. Proceedings of the $13^{\text {th }}$ Australasian Coastal and Ocean Engineering Conference, 2, 941-979. 
Cabral, P., Levrel, H., Schoenn, J., Thiebaut, E., Le Mao, P., Mongruel, R., Rollet, C., Dedieu, K., Carrier, S., \& Morisseau, F. (2015). Marine habitats ecosystem service potential: A vulnerability approach in the Normand-Breton (Saint Malo) Gulf, France. Ecosystem services, 16, 306-318.

Campagne, C. S., Salles, J.-M., Boissery, P., \& Deter, J. (2015). The seagrass Posidonia oceanica: ecosystem services identification and economic evaluation of goods and benefits. Marine Pollution Bulletin, 97(1-2), 391-400.

Cavaloc, E. (1988). Palétuviers Moorea : colonisation des Rhizophora récemment introduits à Moorea (Société, Polynésie française). Bilan de répartition et conséquences écologiques. Rapport EPHEMuseum national d'Histoire naturelle, antenne de Tahiti, $\mathrm{n}^{\circ} 28,35 \mathrm{pp}$.

Cesar, H. (1996). Economic analysis of indonesian coral reefs. The World Bank, Washington DC. 103 pp. Retrieved from: http://siteresources.worldbank.org/INTEEI/2145741153316226850/20486385/EconomicAnalysisofIndonesianCoralReefs1996.pdf

Christianen, M. J., van Belzen, J., Herman, P. M., van Katwijk, M. M., Lamers, L. P., van Leent, P. J., \& Bouma, T. J. (2013). Low-canopy seagrass beds still provide important coastal protection services. PloS one, 8(5), e62413.

CITEPA 2019. Juillet 2019 - Format Outre-mer. URL: https://www.citepa.org/fr/activites/inventaires-desemissions/outre-mer. Accessed February 19, 2020.

Cragg, S. M., Friess, D. A., Gillis, L. G., Trevathan-Tackett, S. M., Terrett, O. M., Watts, J. E., Distel, D. L., \& Dupree, P. (2020). Vascular plants are globally significant contributors to marine carbon fluxes and sinks. Annual Review of Marine Science, 12, 469-497.

Culhane, F. E., Frid, C. L., Gelabert, E. R., Piet, G., White, L., \& Robinson, L. A. (2020). Assessing the capacity of European regional seas to supply ecosystem services using marine status assessments. Ocean \& Coastal Management, 190, 105154.

Culhane, F., Teixeira, H., Nogueira, A. J., Borgwardt, F., Trauner, D., Lillebø, A., Piet, G., Kuemmerlen, M., McDonald, H., \& O'higgins, T. (2019). Risk to the supply of ecosystem services across aquatic ecosystems. Science of The Total Environment, 660, 611-621. 
Dahdouh-Guebas, F., Jayatissa, L. P., Di Nitto, D., Bosire, J. O., Seen, D. L., \& Koedam, N. (2005). How effective were mangroves as a defence against the recent tsunami? Current biology, 15(12), R443R447.

de Arruda Almeida, B., Green, A. J., Sebastián-González, E., \& dos Anjos, L. (2018). Comparing species richness, functional diversity and functional composition of waterbird communities along environmental gradients in the neotropics. PloS one, 13(7), e0200959.

Diop, B., Sanz, N., Blanchard, F., Walcker, R., \& Gardel, A. (2019). The role of mangrove in the French Guiana shrimp fishery. Journal of Environmental Economics and Policy, 8(2), 147-158.

Donato, D. C., Kauffman, J. B., Murdiyarso, D., Kurnianto, S., Stidham, M., \& Kanninen, M. (2011). Mangroves among the most carbon-rich forests in the tropics. Nature geoscience, 4(5), 293.

Duke, N. C. (2014). 'World Mangrove iD: expert information at your fingertips' Google Play Store Version 1.1 for Android, Oct 2014. MangroveWatch Publication, Australia - e-book. ISBN 978-09923659-1-2. Retrieved from: https://play.google.com/store/apps/developer?id=MangroveWatch+Ltd Duke, N. C., Kovacs, J. M., Griffiths, A. D., Preece, L., Hill, D. J., Van Oosterzee, P., Mackenzie, J., Morning, H. S., \& Burrows, D. (2017). Large-scale dieback of mangroves in Australia's Gulf of Carpentaria: a severe ecosystem response, coincidental with an unusually extreme weather event. Marine and Freshwater Research, 68(10), 1816-1829.

Ellison, J. C. (2008). Long-term retrospection on mangrove development using sediment cores and pollen analysis: a review. Aquatic Botany, 89(2), 93-104.

Ellison, J. (2015). Vulnerability assessment of mangroves to climate change and sea-level rise impacts. Wetlands Ecology \& Management, 23(2), 115-137.

Ezcurra, P., Ezcurra, E., Garcillán, P. P., Costa, M. T., \& Aburto-Oropeza, O. (2016). Coastal landforms and accumulation of mangrove peat increase carbon sequestration and storage. Proceedings of the national academy of sciences, 113(16), 4404-4409.

Failler, P., Pètre, É., \& Maréchal, J.-P. (2010). Détermination de la valeur socio-économique des récifs coralliens des mangroves et herbiers de phanérogames de la Martinique. Rapport final pour la Direction Régionale de l’Environnement Martinique. 169 pp. 
Failler, P., Pètre, É., Binet, T., \& Maréchal, J.-P. (2015). Valuation of marine and coastal ecosystem services as a tool for conservation: The case of Martinique in the Caribbean. Ecosystem services, 11, $67-75$.

Fauchille, A. (2003). Colonisation des palétuviers - Rhizophora stylosa - sur l'île de Moorea, Polynésie française. Bilan de répartition et incidence écologique. Rapport 111, EPHE-CRIOBE-Naturalia et Biologia, Moorea, Polynésie française, $44 \mathrm{p}$.

Ferrario, F., Beck, M. W., Storlazzi, C. D., Micheli, F., Shepard, C. C., \& Airoldi, L. (2014). The effectiveness of coral reefs for coastal hazard risk reduction and adaptation. Nature communications, 5(1), 1-9.

Florence, J., Chevillotte, H., Ollier, C., \& Meyer, J-Y. (2013). Nadeaud botanical data base of Herbarium Polynesia (PAP) (Base de données botaniques Nadeaud de l'Herbier de la Polynésie Francaise (PAP)). Retrieved from: http://www.herbier-tahiti.pf.

Folke, C., Carpenter, S., Walker, B., Scheffer, M., Elmqvist, T., Gunderson, L., \& Holling, C. S. (2004). Regime shifts, resilience, and biodiversity in ecosystem management. Annual Review of Ecology, Evolution, and Systematics, 35, 557-581.

France Stratégie (2019). La valeur de l'action pour le climat. Une valeur tutélaire du carbone pour évaluer les investissements et les politiques publiques. Rapport de la commission présidée par A. Quinet. 190 pp. Retrieved from: https://www.strategie.gouv.fr/sites/strategie.gouv.fr/files/atoms/files/fs-2019rapport-la-valeur-de-laction-pour-le-climat_0.pdf

Furlan, E., Torresan, S., Critto, A., Lovato, T., Solidoro, C., Lazzari, P., \& Marcomini, A. (2019). Cumulative Impact Index for the Adriatic Sea: Accounting for interactions among climate and anthropogenic pressures. Science of The Total Environment, 670, 379-397.

Gilman, E., Ellison, J., \& Coleman, R. (2007). Assessment of mangrove response to projected relative sealevel rise and recent historical reconstruction of shoreline position. Environmental Monitoring Assessment 124, 105-130.

Gilman, E. L., Ellison, J., Duke, N. C., \& Field, C. (2008). Threats to mangroves from climate change and adaptation options: a review. Aquatic Botany, 89(2), 237-250. 
Giry, F., Binet, T., \& Keurmeur, N. (2017). Les bénéfices de la protection des mangroves de l'outre-mer français par le Conservatoire du littoral: une évaluation économique à l'horizon 2040. Études caribéennes, 36(36). doi:10.4000/etudescaribeennes.10485

Hamilton, S. E., \& Friess, D. A. (2018). Global carbon stocks and potential emissions due to mangrove deforestation from 2000 to 2012. Nature Climate Change, 8(3), 240.

Herteman, M. (2010). Evaluation des capacités bioremédiatrices d'une mangrove impactée par des eaux usées domestiques. Application au site pilote de Malamani, Mayotte. (PhD), Université Paul Sabatier Toulouse III.

Hughes, T. P. (1994). Catastrophes, phase shifts, and large-scale degradation of a Caribbean coral reef. science, 265(5178), 1547-1551.

Hussain, S. A., \& Badola, R. (2008). Valuing mangrove ecosystem services: linking nutrient retention function of mangrove forests to enhanced agroecosystem production. Wetlands Ecology and Management, 16(6), 441-450.

Hutchison, J., Spalding, M., \& zu Ermgassen, P. (2014). The role of mangroves in fisheries enhancement. The Nature Conservancy and Wetlands International, $54 \mathrm{p}$.

Idier, D., Bertin, X., Thompson, P., \& Pickering, M. D. (2019). Interactions between mean sea level, tide, surge, waves and flooding: mechanisms and contributions to sea level variations at the coast. Surveys in Geophysics, 40(6), 1603-1630.

Igulu, M. M., Nagelkerken, I., Dorenbosch, M., Grol, M. G., Harborne, A. R., Kimirei, I. A., Mumby, P.J., Olds, A.D. \& Mgaya, Y. D. (2014). Mangrove habitat use by juvenile reef fish: meta-analysis reveals that tidal regime matters more than biogeographic region. PloS one, 9(12), e114715.

Iltis, J., \& Meyer, J.-Y. (2010). La mangrove introduite dans les archipels éloignés d'Océanie, entre assimilation et rejet. LEspace geographique, 39(3), 267-275.

INSEE (2017a). Populations légales des départements en 2017. Recensement de la population. Institut national de la statistique et des études économiques. URL: https://www.insee.fr/fr/statistiques/4265390. Accessed April 14, 2020. 
INSEE (2017b). Populations légales des collectivités d'outre-mer en 2017. Recensement de la population. Institut national de la statistique et des études économiques. URL : https://www.insee.fr/fr/statistiques/4265419. Accessed April 14, 2020.

INSEE (2017c). Polynésie Française. Recensement de la population. Institut national de la statistique et des études économiques. URL: https://www.insee.fr/fr/statistiques/3651609. Accessed April 14, 2020.

INSEE (2018). Wallis et Futuna. Recensement de la population. Institut national de la statistique et des études économiques. URL: https://www.insee.fr/fr/statistiques/2121453. Accessed April 14, 2020.

ISEE (2019). Nouvelle-Calédonie. Recensement de la population. Institut de la statistique et des études économiques Nouvelle Calédonie. URL: https://www.isee.nc. Accessed April 14, 2020.

IUCN (2015). Guidelines for the application of IUCN Red List of Ecosystems Categories and Criteria. Bland, L. M., Keith, D. A., Miller, R. M., Murray, N. J., \& Rodríguez, J.P. (eds.) Version 1.0. Gland, Switzerland: IUCN. ix + 93pp. Retrieved from: https://portals.iucn.org/library/node/45794

IUCN French Committee (2017). La Liste rouge des écosystèmes en France - Chapitre Mangroves de Mayotte, Paris, France, 72 pp. Retrieved from: https://uicn.fr/wp-content/uploads/2017/04/uicn-lremayotte-webbd.pdf.

Kauffman, J. B., \& Bhomia, R. K. (2017). Ecosystem carbon stocks of mangroves across broad environmental gradients in West-Central Africa: Global and regional comparisons. PloS one, 12(11), e0187749.

Kristensen, E. (2008). Mangrove crabs as ecosystem engineers; with emphasis on sediment processes. Journal of sea Research, 59(1-2), 30-43.

Kristensen, E., Jensen, M. H., Banta, G. T., Hansen, K., Holmer, M., \& King, G. M. (1998).

Transformation and transport of inorganic nitrogen in sediments of a southeast Asian mangrove forest. Aquatic Microbial Ecology, 15(2), 165-175.

Laliberté, E., \& Legendre, P. (2010). A distance-based framework for measuring functional diversity from multiple traits. Ecology, 91(1), 299-305.

Li, S., Meng, X., Ge, Z., \& Zhang, L. (2015). Evaluation of the threat from sea-level rise to the mangrove ecosystems in Tieshangang Bay, southern China. Ocean \& Coastal Management, 109, 1-8. 
Locatelli, T., Binet, T., Kairo, J. G., King, L., Madden, S., Patenaude, G., Upton, C., \& Huxham, M. (2014). Turning the tide: how blue carbon and payments for ecosystem services (PES) might help save mangrove forests. Ambio, 43(8), 981-995.

Loiseau, N., \& Gaertner, J. C. (2015). Indices for assessing coral reef fish biodiversity: the need for a change in habits. Ecology and Evolution, 5(18), 4018-4027.

López-Rasgado, F. J., Lluch-Cota, S. E., Balart, E. F., \& Herzka, S. Z. (2016). Variation in isotopic trophic structure and fish diversity in mangrove systems subject to different levels of habitat modification in the Gulf of California, México. Bulletin of Marine Science, 92(4), 399-422.

Lovelock, C. E., Cahoon, D. R., Friess, D. A., Guntenspergen, G. R., Krauss, K. W., Reef, R., Rogers, K., Saunders, M. L., Sidik, F., Swales, A. \& Saintilan, N. (2015). The vulnerability of Indo-Pacific mangrove forests to sea-level rise. Nature, 526(7574), 559-563.

Maire, E., Grenouillet, G., Brosse, S., \& Villéger, S. (2015). How many dimensions are needed to accurately assess functional diversity? A pragmatic approach for assessing the quality of functional spaces. Global Ecology and Biogeography, 24(6), 728-740.

Maréchal, J.-P., Meesters, E. H., Vedie, F., \& Hellio, C. (2013). Occurrence of the alien seagrass Halophila stipulacea in Martinique (French West Indies). Marine Biodiversity Records, 6.

Mazda, Y., Magi, M., Ikeda, Y., Kurokawa, T., \& Asano, T. (2006). Wave reduction in a mangrove forest dominated by Sonneratia sp. Wetlands Ecology and Management, 14(4), 365-378.

Mazda, Y., Magi, M., Kogo, M., \& Hong, P. N. (1997). Mangroves as a coastal protection from waves in the Tong King delta, Vietnam. Mangroves and Salt marshes, 1, 127-135.

Mcleod, E., Chmura, G. L., Bouillon, S., Salm, R., Björk, M., Duarte, C. M., Lovelock, C. E., Schlesinger, W. H., \& Silliman, B. R. (2011). A blueprint for blue carbon: toward an improved understanding of the role of vegetated coastal habitats in sequestering CO2. Frontiers in Ecology and the Environment, $9(10), 552-560$.

Melet, A., Meyssignac, B., Almar, R., \& Le Cozannet, G. (2018). Under-estimated wave contribution to coastal sea-level rise. Nature Climate Change, 8(3), 234-239. 
MTES (2018). Base de Données sur les Eaux Résiduaires Urbaines - Année de référence 2017. Ministère de la transition Ecologique et Solidaire. Retrieved from: http://assainissement.developpementdurable.gouv.fr.

Mumby, P. J., Edwards, A. J., Arias-González, J. E., Lindeman, K. C., Blackwell, P. G., Gall, A., Gorczynska, M. I., Harborne, A. R., Pescod, C. L., \& Renken, H. (2004). Mangroves enhance the biomass of coral reef fish communities in the Caribbean. nature, 427(6974), 533-536.

Naeem, S., \& Li, S. (1997). Biodiversity enhances ecosystem reliability. Nature, 390(6659), 507.

Nerem, R. S., Beckley, B. D., Fasullo, J. T., Hamlington, B. D., Masters, D., \& Mitchum, G. T. (2018). Climate-change-driven accelerated sea-level rise detected in the altimeter era. Proceedings of the national academy of sciences, 115(9), 2022-2025.

Otsu, N. (1979). A Threshold Selection Method from Gray-Level Histograms. IEEE Transactions on Systems, Man, and Cybernetics, 9 (1), 62-66.

Pascal, N., Leport, G., Allenbach, M., \& Marchand, C. (2014). Récifs coralliens, mangroves et herbiers de Mayotte: Valeur économique des services écosystémiques. Chapitre I et II: Valeurs d'usages directs et indirects. Documentation Ifrecor. Retrieved from: http://ifrecor-doc.fr/items/show/1650.

Pascal, N., Leport, G., Allenbach, M., \& Marchang, C. (2016). Valeur économique des services rendus par les récifs coralliens et écosystèmes associés des Outre-mer français: Documentation Ifrecor. Retrieved from : http://ifrecor-doc.fr/items/show/1654.

Pendergrass, A. G., Knutti, R., Lehner, F., Deser, C., \& Sanderson, B. M. (2017). Precipitation variability increases in a warmer climate. Scientific reports, 7(1), 17966.

Plaziat, J. C., \& Augustinus, P. G. (2004). Evolution of progradation/erosion along the French Guiana mangrove coast: a comparison of mapped shorelines since the 18th century with Holocene data. Marine Geology, 208(2-4), 127-143.

Quartel, S., Kroon, A., Augustinus, P. P. Van Santen, P. \& Tri., N. (2007). Wave attenuation in coastal mangroves in the Red River Delta, Vietnam. Journal of Asian Earth Sciences, 29, 576-584.

R Development Core Team (2019). R: A language and environment for statistical computing. R Foundation for Statistical Computing, Vienna, Austria. Retrieved from: https://www.R-project.org/. 
Ranasinghe, R., Duong, T. M., Uhlenbrook, S., Roelvink, D., \& Stive, M. (2013). Climate-change impact assessment for inlet-interrupted coastlines. Nature Climate Change, 3(1), 83-87.

Ramus, A. P., Silliman, B. R., Thomsen, M. S., \& Long, Z. T. (2017). An invasive foundation species enhances multifunctionality in a coastal ecosystem. Proceedings of the national academy of sciences, $114(32), 8580-8585$.

REVOSIMA (2019). Réseau de surveillance Volcanologique et Sismologique de Mayotte. Bulletin $\mathrm{n}^{\circ} 7 \mathrm{du}$ 16 au 31 octobre 2019. Retrieved from: www.ipgp.fr/revosima-23/23

Rosentreter, J. A., Maher, D. T., Erler, D. V., Murray, R. H., \& Eyre, B. D. (2018). Methane emissions partially offset "blue carbon" burial in mangroves. Science advances, 4(6), eaao4985.

Roussel, E., \& Rivasseau, V. (2008). Les mangroves de l'Outre-mer français - Ecosystèmes associés aux récifs coralliens. Conservatoire du Littoral. 145 pp. Retrieved from : $\underline{\text { http://ifrecor- }}$ $\underline{\text { doc.fr/items/show/1481. }}$

Running, S. W., Nemani, R. R., Heinsch, F. A., Zhao, M., Reeves, M., \& Hashimoto, H. (2004). A Continuous Satellite-Derived Measure of Global Terrestrial Primary Production. BioScience, 54(6), $547-560$.

Salvat, B., Aubanel, A., Adjeroud, M., Bouisset, P., Calmet, D., Chancerelle, Y., Cochennec, N., Davies, N., Fougerousse, A., \& Galzin, R. (2008). Le suivi de l'état des récifs coralliens de Polynésie Française et leur récente évolution. Revue d'écologie, 63, 145-177.

Sasmito, S. D., Kuzyakov, Y., Lubis, A. A., Murdiyarso, D., Hutley, L. B., Bachri, S., Friess, D. A., Martius, C., \& Borchard, N. (2020). Organic carbon burial and sources in soils of coastal mudflat and mangrove ecosystems. Catena, 187, 104414.

Schröter, D., Cramer, W., Leemans, R., Prentice, I. C., Araújo, M. B., Arnell, N. W., Bondeau, A., Bugmann, H., Carter, T. R., \& Gracia, C. A. (2005). Ecosystem service supply and vulnerability to global change in Europe. science, 310(5752), 1333-1337.

Shepard, C. C., Crain, C. M., \& Beck, M. W. (2011). The protective role of coastal marshes: a systematic review and meta-analysis. PloS one, 6(11), e27374. 
Spalding, M., Kainuma, M., Collins, L. (2010). World Atlas of Mangroves (version 3). A collaborative project of ITTO, ISME, FAO, UNEP-WCMC, UNESCO-MAB, UNU-INWEH and TNC. London (UK): Earthscan, London. 319 pp. URL: data.unep-wcmc.org/datasets/5

Sutton-Grier, A. E., \& Moore, A. (2016). Leveraging carbon services of coastal ecosystems for habitat protection and restoration. Coastal Management, 44(3), 259-277.

TAAF (2020). Les îles Eparses (Scattered Islands). Retrieved from: https://taaf.fr/collectivites/presentation-des-territoires/les-iles-eparses/.

Taillardat, P., Friess, D. A., \& Lupascu, M. (2018). Mangrove blue carbon strategies for climate change mitigation are most effective at the national scale. Biology letters, 14(10), 20180251.

Tanner, M. K., Moity, N., Costa, M. T., Jarrin, J. R. M., Aburto-Oropeza, O., \& Salinas-de-León, P. (2019). Mangroves in the Galapagos: ecosystem services and their valuation. Ecological economics, $160,12-24$.

Taureau, F. (2017). Cartographie harmonisée des mangroves de l'Outre-mer français. PhD thesis. Université Bretagne Loire - Nantes, 248 pp.

Taureau, F. (2019). Surveillons la mangrove de Polynésie Française ensemble: Etude cartographique dans les îles de la Société. Université de Nantes, 38 pp.

Thollot P. (1992). Les poissons de mangrove du lagon sud-ouest de Nouvelle-Calédonie. PhD thesis. Université Aix-Marseille 2, Marseille, France. 406 pp.

Thur, S. M. (2010). User fees as sustainable financing mechanisms for marine protected areas: An application to the Bonaire National Marine Park. Marine Policy, 34(1), 63-69.

Trégarot, E., Failler, P., \& Maréchal, J.-P. (2017). Evaluation of coastal and marine ecosystem services of Mayotte: Indirect use values of coral reefs and associated ecosystems. International Journal of Biodiversity Science, Ecosystem Services \& Management, 13(3), 19-34.

Vaz, A. S., Kueffer, C., Kull, C. A., Richardson, D. M., Vicente, J. R., Kühn, I., Schröter, M., Hauck, J., Bonn, A., \& Honrado, J. P. (2017). Integrating ecosystem services and disservices: insights from plant invasions. Ecosystem services, 23, 94-107. 
Ventura, A. d. O. B., \& da Cunha Lana, P. (2014). A new empirical index for assessing the vulnerability of peri-urban mangroves. Journal of environmental management, 145, 289-298.

Villéger, S., Mason, N. W., \& Mouillot, D. (2008). New multidimensional functional diversity indices for a multifaceted framework in functional ecology. Ecology, 89(8), 2290-2301.

Vovides, A. G., Vogt, J., Kollert, A., Berger, U., Grueters, U., Peters, R., Lara-Domínguez, A.L., \& LópezPortillo, J. (2014). Morphological plasticity in mangrove trees: salinity-related changes in the allometry of Avicennia germinans. Trees, 28(5), 1413-1425.

Walcker, R., Gratiot, N., \& Anthony, E. J. (2016). Remote sensing-based monitoring of the muddy mangrove coastline of French Guiana. In N. Baghdadi \& M. Zribi (Eds.), Land surface remote sensing in urban and coastal areas (pp. 297-320): Elsevier.

Walcker, R., Gandois, L., Proisy, C., Corenblit, D., Mougin, E., Laplanche, C., Ray, R., \& Fromard, F. (2018). Control of "blue carbon" storage by mangrove ageing: Evidence from a 66-year chronosequence in French Guiana. Global change biology, 24(6), 2325-2338.

Walcker, R., Laplanche, C., Herteman, M., Lambs, L., \& Fromard, F. (2019). Damages caused by hurricane Irma in the human-degraded mangroves of Saint Martin (Caribbean). Scientific reports, $9(1), 1-11$.

Walker, B. (1995). Conserving biological diversity through ecosystem resilience. Conservation Biology, 9(4), 747-752.

Wang, H., Gilbert, J. A., Zhu, Y., \& Yang, X. (2018). Salinity is a key factor driving the nitrogen cycling in the mangrove sediment. Science of The Total Environment, 631, 1342-1349.

Wang, L., Jia, M., Yin, D., \& Tian, J. (2019). A review of remote sensing for mangrove forests: 19562018. Remote Sensing of Environment, 231, 111223.

Ward, R. D., Friess, D. A., Day, R. H., \& MacKenzie, R. A. (2016). Impacts of climate change on mangrove ecosystems: a region by region overview. Ecosystem Health and Sustainability, 2(4), $\mathrm{e} 01211$.

Wells, S., and C. Ravilious. 2006. In the front line: shoreline protection and other ecosystem services from mangroves and coral reefs. UNEP/Earthprint. 
Woodroffe, C. D., Rogers, K., McKee, K. L., Lovelock, C. E., Mendelssohn, I., \& Saintilan, N. (2016). Mangrove sedimentation and response to relative sea-level rise. Annual Review of Marine Science, 8 , 243-266.

Wunder, S. (2015). Revisiting the concept of payments for environmental services. Ecological economics, $117,234-243$.

Xiao, K., Wu, J., Li, H., Hong, Y., Wilson, A. M., Jiao, J. J., \& Shananan, M. (2018). Nitrogen fate in a subtropical mangrove swamp: Potential association with seawater-groundwater exchange. Science of The Total Environment, 635, 586-597. doi:10.1016/j.scitotenv.2018.04.143

Zhao, M., Heinsch, F. A., Nemani, R. R., \& Running, S. W. (2005). Improvements of the MODIS terrestrial gross and net primary production global data set. Remote Sensing of Environment, 95(2), $164-176$. 


\section{Supplementary materials}

\section{Figure S1}

Operational flow-chart for the mapping of mangroves

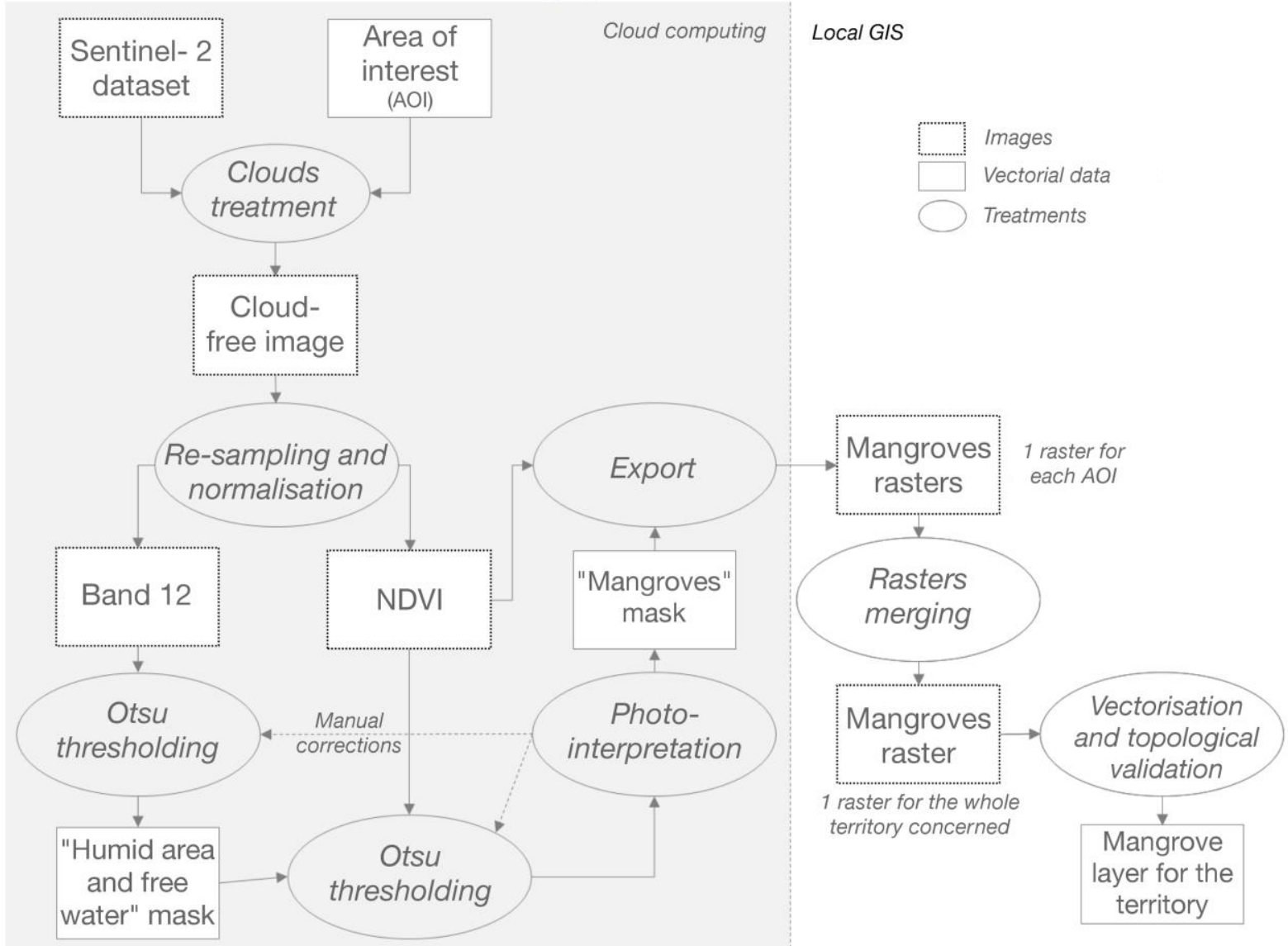




\section{Figure S2}

Example of a simplified geometry of mangrove patch in French Guiana for MODIS Net Primary Production evaluation.

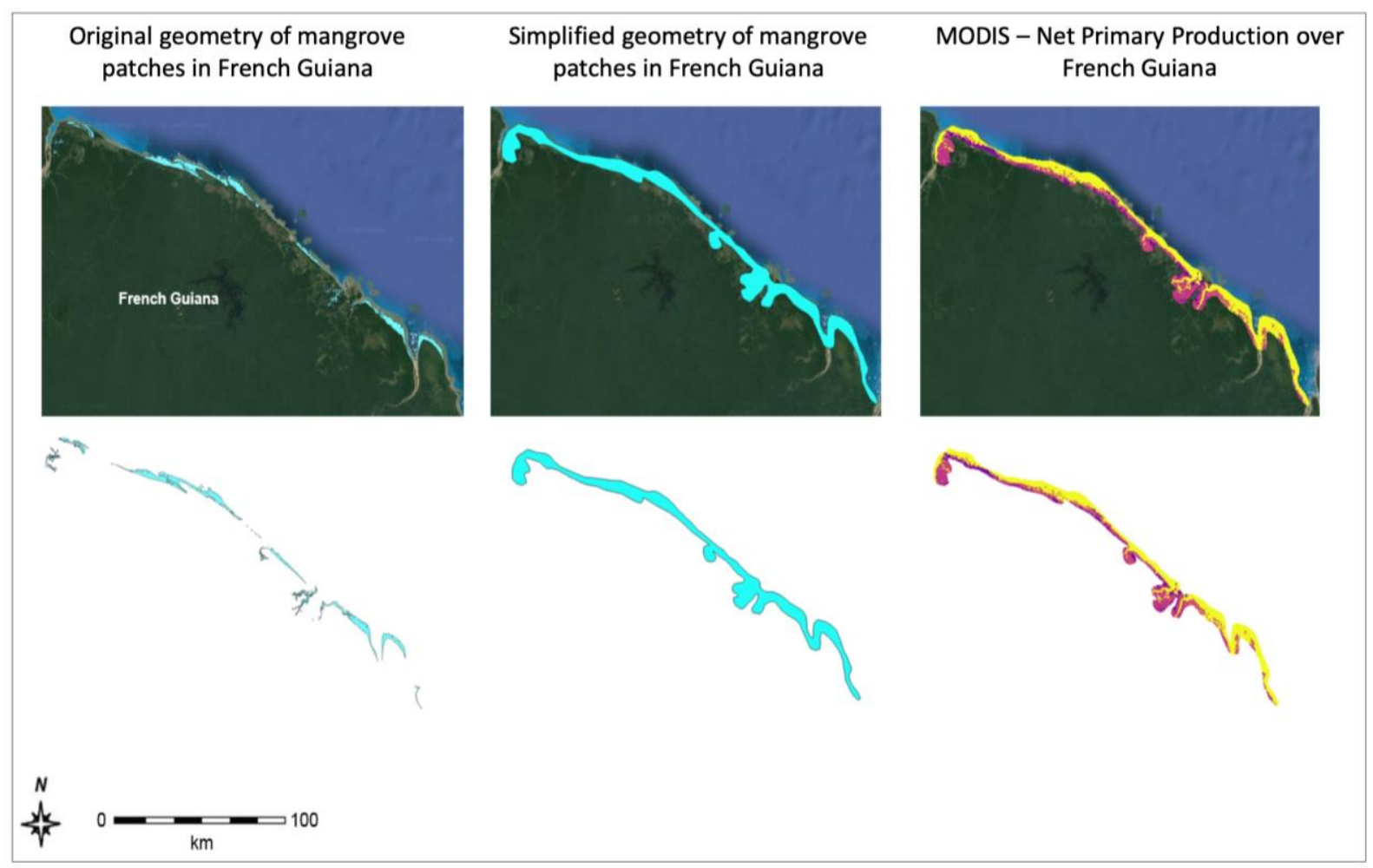

\section{Table S1}

Mangroves species functional traits database for the computation of functional biodiversity indices in the French Overseas territories. Traits compiled from Duke (2014).

\begin{tabular}{|l|l|l|l|l|l|}
\hline Species & Tidal & Estuarine position & $\begin{array}{l}\text { Size } \\
(\mathbf{m})\end{array}$ & $\begin{array}{l}\text { Growth } \\
\text { Type }\end{array}$ & Roots \\
\hline Acanthus ilicifolius & High_Low & Intermediate_upstream & 2 & shrub_herb & aerial_prop_roots \\
\hline Avicennia germinans & High_Mid & Downstream_intermediate & 25 & tree_shrub & pneumatophores \\
\hline Avicennia marina & High_Low & Downstream_intermediate & 10 & tree_shrub & pneumatophores \\
\hline Avicennia schaueriana & High_Mid & Intermediate_upstream & 15 & tree_shrub & pneumatophores \\
\hline Cynometra iripa & High & Intermediate_upstream & 15 & tree_shrub & below_ground \\
\hline Conocarpus erectus & High & Downstream_intermediate & 3 & shrub_tree & below_ground \\
\hline
\end{tabular}




\begin{tabular}{|c|c|c|c|c|c|}
\hline Laguncularia racemosa & Mid_Low & Downstream_upstream & 25 & tree_shrub & root_knees \\
\hline Lumnitzera littorea & Mid & Intermediate & 25 & tree_shrub & root_knees \\
\hline Lumnitzera racemosa & High_Mid & Downstream_intermediate & 15 & tree_shrub & root_knees \\
\hline Lumnitzera rosea & High & Intermediate & 2 & shrub & root_knees \\
\hline Excoecaria agallocha & High_Mid & Downstream_upstream & 7 & tree_shrub & serpentine_knotted_lenticellate \\
\hline Crenea patentinervis & High & Intermediate_upstream & 1 & shrub & below_ground \\
\hline Pemphis acidula & High & Downstream_offshore & 7 & shrub_tree & aerial_looping \\
\hline Pavonia paludicola & High & Upstream & 5 & shrub & below_ground \\
\hline Xylocarpus granatum & High_Mid & Intermediate & 22 & tree & serpentine_ribbon-like \\
\hline Xylocarpus moluccensis & High_Mid & Intermediate & 15 & tree & pneumatophores \\
\hline Acrostichum aureum & High & Upstream & 4 & fern & below_ground \\
\hline Acrostichum danaeifolium & High_Low & Intermediate_upstream & 3 & fern & below_ground \\
\hline Acrostichum speciosum & High & Intermediate & 1,5 & fern & below_ground \\
\hline Bruguiera gymnorhiza & High_Mid & Downstream_intermediate & 25 & tree_shrub & pneumatophores \\
\hline Ceriops tagal & High_Mid & Downstream_intermediate & 25 & tree_shrub & aerial_looping \\
\hline Rhizophora apiculata & Mid & Intermediate & 30 & tree & sturdy_props_lenticellate \\
\hline Rhizophora lamarckii & Mid & Downstream_intermediate & 25 & tree & sturdy_props_lenticellate \\
\hline Rhizophora mangle & Mid_Low & Downstream_upstream & 40 & tree & sturdy_props_lenticellate \\
\hline Rhizophora racemosa & Mid_Low & Downstream_offshore & 50 & tree & sturdy_props_lenticellate \\
\hline Rhizophora mucronata & Mid_Low & Intermediate_upstream & 20 & tree & sturdy_props_lenticellate \\
\hline Rhizophora samoensis & Mid_Low & Intermediate_upstream & 40 & tree & Sturdy_props_lenticellate \\
\hline Rhizophora selala & High_Mid & Downstream_intermediate & 20 & tree & Sturdy_props_lenticellate \\
\hline Rhizophora stylosa & Mid_Low & Downstream_offshore & 30 & tree & Sturdy_props_lenticellate \\
\hline Rhizophora tomlinsonii & High_Mid & Intermediate & 8 & tree & sturdy_props_lenticellate \\
\hline Scyphiphora hydrophylacea & High & Intermediate & 2 & shrub & below_ground \\
\hline Sonneratia alba & Low & Downstream_offshore & 20 & tree & pneumatophores \\
\hline Sonneratia caseolaris & Low & Upstream & 20 & tree & pneumatophores \\
\hline
\end{tabular}




\begin{tabular}{|c|c|c|c|c|c|c|c|}
\hline Species & $\begin{array}{l}\text { Leaves } \\
\text { type }\end{array}$ & $\begin{array}{l}\text { Leaves } \\
\text { length_(cm) }\end{array}$ & $\begin{array}{l}\text { Inflorescence } \\
\text { type }\end{array}$ & Fruit & Release & $\begin{array}{l}\text { Seeds } \\
\text { number }\end{array}$ & Germination \\
\hline Acanthus ilicifolius & simple & 20 & spike & Capsule & Seeds & Solitary & hypogeal \\
\hline Avicennia germinans & simple & 11,1 & spike & Pod & Propagule & Solitary & cryptoviviparous \\
\hline Avicennia marina & simple & 8,4 & capitulum & Pod & Propagule & Solitary & cryptoviviparous \\
\hline Avicennia schaueriana & simple & 11,1 & spike & Pod & Propagule & Solitary & cryptoviviparous \\
\hline Cynometra iripa & compound & 13 & capitulum & Pod & Seeds & Solitary & epigeal \\
\hline Conocarpus erectus & simple & 9 & panicle & Nutlet & Seeds & Numerous & hypogeal \\
\hline Laguncularia racemosa & simple & 8 & raceme & Nutlet & Propagule & Solitary & epigeal \\
\hline Lumnitzera littorea & simple & 9 & raceme & Drupe & Seeds & Solitary & hypogeal \\
\hline Lumnitzera racemosa & simple & 6 & raceme & Drupe & Seeds & Solitary & hypogeal \\
\hline Lumnitzera rosea & simple & 6 & raceme & Drupe & Seeds & Solitary & cryptoviviparous \\
\hline Excoecaria agallocha & simple & 10,5 & catkins & Capsule & Seeds & Numerous & epigeal \\
\hline Pemphis acidula & simple & 3 & solitary & Capsule & Seeds & Numerous & embryo_minute \\
\hline Pavonia paludicola & simple & 14 & raceme & Capsule & Seeds & Unknown & unknown \\
\hline Xylocarpus granatum & compound & 20 & panicle & Capsule & Seeds & Numerous & hypogeal \\
\hline Xylocarpus moluccensis & compound & 10 & panicle & Capsule & Seeds & Numerous & hypogeal \\
\hline Acrostichum aureum & pinnate & 40 & absent & absent & Spore & Numerous & spore \\
\hline Acrostichum danaeifolium & pinnate & 40 & absent & absent & Spore & Numerous & spore \\
\hline Acrostichum speciosum & pinnate & 20 & absent & absent & Spore & Numerous & spore \\
\hline Bruguiera gymnorhiza & simple & 24 & solitary & Drupe & Propagule & Solitary & viviparous \\
\hline Ceriops tagal & simple & 7 & cyme & $\begin{array}{l}\text { Drupe- } \\
\text { like }\end{array}$ & Propagule & Solitary & viviparous \\
\hline Rhizophora apiculata & simple & 19 & branching_bifurcate & $\begin{array}{l}\text { Drupe- } \\
\text { like }\end{array}$ & Propagule & Solitary & viviparous \\
\hline Rhizophora lamarckii & simple & 15 & branching_bifurcate & $\begin{array}{l}\text { Drupe- } \\
\text { like }\end{array}$ & Propagule & Solitary & viviparous \\
\hline
\end{tabular}




\begin{tabular}{|c|c|c|c|c|c|c|c|}
\hline Rhizophora mangle & simple & 12 & $\begin{array}{l}\text { branching_bifurcate } \\
\text { _trifurcate }\end{array}$ & $\begin{array}{l}\text { Drupe- } \\
\text { like }\end{array}$ & Propagule & Solitary & viviparous \\
\hline Rhizophora racemosa & simple & 19 & branching_bifurcate & $\begin{array}{l}\text { Drupe- } \\
\text { like }\end{array}$ & Propagule & Solitary & viviparous \\
\hline Rhizophora mucronata & simple & 17 & $\begin{array}{l}\text { branching_dichotom } \\
\text { ous }\end{array}$ & $\begin{array}{l}\text { Drupe- } \\
\text { like }\end{array}$ & Propagule & Solitary & viviparous \\
\hline Rhizophora samoensis neocaledonica & simple & 11,3 & $\begin{array}{l}\text { branching_bifurcate } \\
\text { _trifurcate }\end{array}$ & Hybrid & Hybrid & Hybrid & hybrid \\
\hline Rhizophora samoensis & simple & 14 & $\begin{array}{l}\text { branching_bifurcate } \\
\text { _trifurcate }\end{array}$ & $\begin{array}{l}\text { Drupe- } \\
\text { like }\end{array}$ & Propagule & Solitary & viviparous \\
\hline Rhizophora selala & simple & 14 & $\begin{array}{l}\text { branching_dichotom } \\
\text { ous_trifurcate }\end{array}$ & Hybrid & Hybrid & Hybrid & hybrid \\
\hline Rhizophora stylosa & simple & 14 & $\begin{array}{l}\text { branching_dichotom } \\
\text { ous }\end{array}$ & $\begin{array}{l}\text { Drupe- } \\
\text { like }\end{array}$ & Propagule & Solitary & viviparous \\
\hline Rhizophora tomlinsonii & simple & 21 & $\begin{array}{l}\text { branching_bifurcate } \\
\text { _trifurcate }\end{array}$ & Hybrid & Hybrid & Hybrid & hybrid \\
\hline Scyphiphora hydrophylacea & simple & 9 & cyme & Drupe & Seeds & Numerous & hypogeal \\
\hline Sonneratia alba & simple & 12 & dichasia & Berry & Seeds & Numerous & epigeal \\
\hline Sonneratia caseolaris & simple & 11 & dichasia & Berry & Seeds & Numerous & epigeal \\
\hline
\end{tabular}

\section{Table S2}

Presence/Absence database of mangrove species in the French Overseas Territories for the computation of functional biodiversity indices (French Polynesia excluded).

\begin{tabular}{|c|c|c|c|c|c|c|c|c|c|}
\hline Species & FG & MQ & $\mathbf{G}$ & SB & SM & MY & SI & $\mathbf{N C}$ & $\mathbf{W F}$ \\
\hline Acanthus_ilicifolius & 0 & 0 & 0 & 0 & 0 & 0 & 0 & 1 & 0 \\
\hline Acrostichum_aureum & 1 & 1 & 1 & 0 & 0 & 1 & 0 & 0 & 0 \\
\hline Acrostichum_danaeifolium & 1 & 1 & 1 & 0 & 0 & 0 & 0 & 0 & 0 \\
\hline Acrostichum_speciosum & 0 & 0 & 0 & 0 & 0 & 0 & 0 & 1 & \\
\hline Avicennia_germinans & 1 & 1 & 1 & 1 & 1 & 0 & 0 & 0 & 0 \\
\hline Avicennia_marina & 0 & 0 & 0 & 0 & 0 & 1 & 1 & 1 & 0 \\
\hline
\end{tabular}




\begin{tabular}{|c|c|c|c|c|c|c|c|c|c|}
\hline Avicennia_schaueriana & 0 & 1 & 1 & 0 & 0 & 0 & 0 & 0 & 0 \\
\hline Bruguiera_gymnorhiza & 0 & 0 & 0 & 0 & 0 & 1 & 1 & 1 & 1 \\
\hline Ceriops_tagal & 0 & 0 & 0 & 0 & 0 & 1 & 1 & 1 & 0 \\
\hline Conocarpus_erectus & 1 & 1 & 1 & 1 & 1 & 0 & 0 & 0 & 0 \\
\hline Cynometra_iripa & 0 & 0 & 0 & 0 & 0 & 0 & 0 & 1 & 0 \\
\hline Excoecaria_agallocha & 0 & 0 & 0 & 0 & 0 & 0 & 0 & 1 & 0 \\
\hline Laguncularia_racemosa & 1 & 1 & 1 & 1 & 1 & 0 & 0 & 0 & 0 \\
\hline Lumnitzera_littorea & 0 & 0 & 0 & 0 & 0 & 0 & 0 & 1 & 0 \\
\hline Lumnitzera_racemosa & 0 & 0 & 0 & 0 & 0 & 1 & 0 & 1 & 0 \\
\hline Lumnitzera_x_rosea & 0 & 0 & 0 & 0 & 0 & 0 & 0 & 1 & 0 \\
\hline Pavonia_paludicola & 1 & 1 & 1 & 0 & 0 & 0 & 0 & 0 & 0 \\
\hline Pemphis_acidula & 0 & 0 & 0 & 0 & 0 & 1 & 0 & 1 & 0 \\
\hline Rhizophora_apiculata & 0 & 0 & 0 & 0 & 0 & 0 & 0 & 1 & 0 \\
\hline Rhizophora_lamarckii & 0 & 0 & 0 & 0 & 0 & 0 & 0 & 1 & 0 \\
\hline Rhizophora_mangle & 1 & 1 & 1 & 1 & 1 & 0 & 0 & 0 & 0 \\
\hline Rhizophora_mucronata & 0 & 0 & 0 & 0 & 0 & 1 & 1 & 0 & 0 \\
\hline Rhizophora_racemosa & 1 & 0 & 0 & 0 & 0 & 0 & 0 & 0 & 0 \\
\hline Rhizophora_samoensis & 0 & 0 & 0 & 0 & 0 & 0 & 0 & 1 & 1 \\
\hline Rhizophora_selala & 0 & 0 & 0 & 0 & 0 & 0 & 0 & 1 & 0 \\
\hline Rhizophora_stylosa & 0 & 0 & 0 & 0 & 0 & 0 & 0 & 1 & 1 \\
\hline Rhizophora_tomlinsonii & 0 & 0 & 0 & 0 & 0 & 0 & 0 & 1 & 0 \\
\hline Scyphiphora_hydrophylacea & 0 & 0 & 0 & 0 & 0 & 0 & 0 & 1 & 0 \\
\hline Sonneratia_alba & 0 & 0 & 0 & 0 & 0 & 1 & 0 & 1 & 0 \\
\hline Sonneratia_caseolaris & 0 & 0 & 0 & 0 & 0 & 0 & 0 & 1 & 0 \\
\hline Xylocarpus_granatum & 0 & 0 & 0 & 0 & 0 & 1 & 0 & 1 & 0 \\
\hline Xylocarpus_moluccensis & 0 & 0 & 0 & 0 & 0 & 0 & 0 & 1 & 0 \\
\hline
\end{tabular}

FG: French Guiana, MQ: Martinique, G: Guadeloupe, SB: Saint-Barthelemy, SM: Saint-Martin, MY: Mayotte, SI: Scattered Islands, WF: Wallis and Futuna. 


\section{Table S3}

Functional biodiversity indices (FDis: Functional dispersion; FOri: Functional Originality) and associated vulnerability scores of mangroves in the French Overseas territories

\begin{tabular}{|l|r|r|r|r|r|r|r|r|r|}
\hline & FG & MQ & G & SM & SB & MY & SI & NC & WF \\
\hline FDis & 0,908 & 0,900 & 0,914 & 0,720 & 0,720 & 0,807 & 0,571 & 0,721 & 0,720 \\
\hline Score & 1 & 1 & 1 & 2 & 2 & 1 & 3 & 2 & 2 \\
\hline FOri & 0,420 & 0,346 & 0,412 & 0,449 & 0,449 & 0,373 & 0,462 & 0,428 & 0,309 \\
\hline Score & 3 & 2 & 3 & 3 & 3 & 2 & 3 & 3 & 2 \\
\hline
\end{tabular}

FG: French Guiana, G: Guadeloupe, MQ: Martinique, SM: Saint-Martin, SB: Saint-Barthelemy, MY: Mayotte, SI: Scattered Islands, NC: New Caledonia, WF: Wallis and Futuna.

\section{Table S4}

Literature review of the annual cost of the four artificial structures most commonly implemented for coastal protection.

\begin{tabular}{|c|c|c|c|c|c|}
\hline $\begin{array}{l}\text { Type of } \\
\text { structure }\end{array}$ & Country & Year & $\begin{array}{l}\text { Cost }(€ / \mathrm{km} / \text { year }) \text { as of } \\
2017\end{array}$ & Sources & $\begin{array}{l}2017 \text { GDP } \\
\text { PPP Per } \\
\text { capita * }\end{array}$ \\
\hline \multirow[t]{5}{*}{ Breakwaters } & France & 2004 & 753,495 to 869,417 & $\begin{array}{l}\text { Delangue and Teillac- } \\
\text { Deschamps, } 2018\end{array}$ & $€ 37,259$ \\
\hline & France & 2004 & $1,167,917$ to $1,347,597$ & $\begin{array}{l}\text { Delangue and Teillac- } \\
\text { Deschamps, } 2018\end{array}$ & $€ 37,259$ \\
\hline & Maldives & 2008 & 120538 to 168363 & Emerton et al., 2009 & $€ 13,405$ \\
\hline & Maldives & 2008 & 204915 to 286218 & Emerton et al., 2009 & $€ 13,405$ \\
\hline & Netherlands & 2011 & 248995 to 380382 & van Rijn, 2011 & $€ 45,493$ \\
\hline
\end{tabular}




\begin{tabular}{|c|c|c|c|c|c|}
\hline \multirow[t]{8}{*}{$\begin{array}{l}\text { Type of } \\
\text { structure }\end{array}$} & Country & Year & $\begin{array}{l}\text { Cost }(€ / \mathrm{km} / \text { year }) \text { as of } \\
2017\end{array}$ & Sources & $\begin{array}{l}2017 \text { GDP } \\
\text { PPP Per } \\
\text { capita * }\end{array}$ \\
\hline & Netherlands & 2011 & 248995 to 507176 & van Rijn, 2011 & $€ 45,493$ \\
\hline & Netherlands & 2011 & 316985 to 633970 & van Rijn, 2011 & $€ 45,493$ \\
\hline & Netherlands & 2014 & 1458441 to 8414081 & $\begin{array}{l}\text { Climate ADAPT - The } \\
\text { European Climate } \\
\text { Adaptation Platform, } 2015\end{array}$ & $€ 45,493$ \\
\hline & Sri Lanka & 1994 & 172605 to 199160 & $\begin{array}{l}\text { Möberg and Rönnbäck, } \\
2003\end{array}$ & $€ 10,837$ \\
\hline & $\begin{array}{l}\text { United Kingdom } \\
\text { (Scotland) }\end{array}$ & 2000 & 97984 to 282646 & Hudson et al., 2015 & $€ 38,192$ \\
\hline & United Kingdom & 2007 & 512940 to 1014607 & Hudson et al., 2015 & $€ 38,192$ \\
\hline & $\begin{array}{l}\text { United Kingdom } \\
\text { (Wales) }\end{array}$ & 2012 & 401945 to 463783 & $\begin{array}{l}\text { Field Studies Council, } \\
2012\end{array}$ & $€ 38,192$ \\
\hline \multirow[t]{5}{*}{ Seawalls } & $\begin{array}{l}\text { France (La } \\
\text { Réunion) }\end{array}$ & 2016 & 1534781 to 1770902 & Gaudieux et al., 2016 & $€ 37,259$ \\
\hline & Netherlands & 2011 & 190191 to 380382 & van Rijn, 2011 & $€ 45,493$ \\
\hline & South Africa & 2008 & 69429 to 801102 & Hillen et al., 2010 & $€ 12,107$ \\
\hline & $\begin{array}{l}\text { United Kingdom } \\
\text { (Scotland) }\end{array}$ & 2000 & 489920 to 1413231 & Hudson et al., 2015 & $€ 38,192$ \\
\hline & United Kingdom & 2007 & 205176 to 1826292 & Hudson et al., 2015 & $€ 38,192$ \\
\hline
\end{tabular}




\begin{tabular}{|c|c|c|c|c|c|}
\hline $\begin{array}{l}\text { Type of } \\
\text { structure }\end{array}$ & Country & Year & $\begin{array}{l}\text { Cost }(€ / \mathrm{km} / \text { year }) \text { as of } \\
2017\end{array}$ & Sources & $\begin{array}{l}2017 \text { GDP } \\
\text { PPP Per } \\
\text { capita * }\end{array}$ \\
\hline & $\begin{array}{l}\text { United Kingdom } \\
\text { (Wales) }\end{array}$ & 2012 & 803,889 to $1,391,347$ & $\begin{array}{l}\text { Field Studies Council, } \\
2012\end{array}$ & $€ 38,192$ \\
\hline & USA & 2005 & $5,513,951$ to $6,362,251$ & Dawson et al., 2013 & $€ 51,845$ \\
\hline & USA & 2007 & $1,012,081$ & Hillen et al., 2010 & $€ 51,845$ \\
\hline & USA & 2010 & $2,593,602$ to $3,300,948$ & King et al., 2011 & $€ 51,845$ \\
\hline & USA & 2010 & $2,251,391$ to $2,865,407$ & King et al., 2011 & $€ 51,845$ \\
\hline & USA & 2010 & 415,334 to 479,231 & King et al., 2011 & $€ 51,845$ \\
\hline & USA & 2010 & $1,059,102$ to $1,222,041$ & King et al., 2011 & $€ 51,845$ \\
\hline & USA & 2013 & $1,036,063$ to $1,195,457$ & Dawson et al., 2013 & $€ 51,845$ \\
\hline & Vietnam & 2011 & 40 to 46 & Perez et al., 2013 & $€ 5,433$ \\
\hline Rock Fills & France & 2002 & 98,314 to 471,208 & $\begin{array}{l}\text { Delangue and Teillac- } \\
\text { Deschamps, } 2018\end{array}$ & $€ 37,259$ \\
\hline & France & 2015 & 130,000 to 225,001 & Tresca, 2015 & $€ 37,259$ \\
\hline & France & 2015 & $1,495,001$ to $1,725,001$ & $\begin{array}{l}\text { Ville de Lacanau and GIP } \\
\text { Littoral Aquitain, } 2015\end{array}$ & $€ 37,259$ \\
\hline & France & 2015 & $2,236,001$ to $2,580,001$ & $\begin{array}{l}\text { Ville de Lacanau and GIP } \\
\text { Littoral Aquitain, } 2015\end{array}$ & $€ 37,259$ \\
\hline & Netherlands & 2011 & 126,794 to 253,588 & van Rijn, 2011 & $€ 45,493$ \\
\hline
\end{tabular}




\begin{tabular}{|c|c|c|c|c|c|}
\hline \multirow[t]{5}{*}{$\begin{array}{l}\text { Type of } \\
\text { structure }\end{array}$} & Country & Year & $\begin{array}{l}\text { Cost }(€ / \mathrm{km} / \text { year }) \text { as of } \\
2017\end{array}$ & Sources & $\begin{array}{l}2017 \text { GDP } \\
\text { PPP Per } \\
\text { capita* }\end{array}$ \\
\hline & $\begin{array}{l}\text { United Kingdom } \\
\text { (Scotland) }\end{array}$ & 2000 & 244,960 to 847,938 & Hudson et al., 2015 & $€ 38,192$ \\
\hline & $\begin{array}{l}\text { United Kingdom } \\
\text { (Scotland) }\end{array}$ & 2000 & 48,992 to 169,588 & Hudson et al., 2015 & $€ 38,192$ \\
\hline & United Kingdom & 2007 & 395,696 to $2,029,214$ & Hudson et al., 2015 & $€ 38,192$ \\
\hline & United Kingdom & 2007 & 190,521 to 963,877 & Hudson et al., 2015 & $€ 38,192$ \\
\hline \multirow[t]{6}{*}{$\begin{array}{l}\text { Artificial } \\
\text { Reefs }\end{array}$} & France & 2004 & 251,102 & $\begin{array}{l}\text { Delangue and Teillac- } \\
\text { Deschamps, } 2018\end{array}$ & $€ 37,259$ \\
\hline & France & 2015 & $1,333,000$ & $\begin{array}{l}\text { Ville de Lacanau and GIP } \\
\text { Littoral Aquitain, } 2015\end{array}$ & $€ 37,259$ \\
\hline & India & 2017 & 21,460 & Black et al., 2017 & $€ 13,405$ \\
\hline & Mexico & 2013 & 6,885 & Silva et al., 2017 & $€ 15,834$ \\
\hline & Netherlands & 2014 & $2,243,194$ to $5,234,119$ & $\begin{array}{l}\text { Climate ADAPT - The } \\
\text { European Climate } \\
\text { Adaptation Platform, } 2015\end{array}$ & $€ 45,493$ \\
\hline & United Kingdom & 2000 & 50,236 to 150,707 & $\begin{array}{l}\text { Climate ADAPT - The } \\
\text { European Climate } \\
\text { Adaptation Platform, } 2015\end{array}$ & $€ 38,192$ \\
\hline
\end{tabular}

* The World Bank, World Development Indicators, 2017. GDP PPP Per capita. Retrieved from https://databank.worldbank.org/data/reports.aspx? source=2\&series=NY.GDP.PCAP.PP.CD 
Table S5

Reference values for denitrification rates in mangroves

\begin{tabular}{|l|l|l|}
\hline Country & Denitrification rates $\left(\mathbf{k g N ~ h a} \mathbf{~}^{-\mathbf{1}} \mathbf{y r}^{-\mathbf{1}}\right)$ & Sources \\
\hline Puerto Rico & $19.18 ; 12.53 ; 16.09 ; 2.13 ; 7.74 ; 22.4 ; 3.3 ;$ & Corredor and Morell, 1994 \\
\hline Puerto Rico & 10.25 & Corredor and Morell, 1999 \\
\hline Thailand & $11.04 ; 4.91 ; 19.62 ; 12.26$ & Alongi et al., 2002 \\
\hline Australia & 18.92 & Iizumi, 1986 \\
\hline Mexico & $13.86 ; 0.01 ; 1.15$ & Rivera-Monroy et al., 1996 \\
\hline India & 17.17 & Fernandes et al. ,2010 \\
\hline
\end{tabular}

\section{Table S6}

Cost of water treatment (used for the calculation of the cost of removing $1 \mathrm{kgN}$ ) in French

Overseas territories.

\begin{tabular}{|l|l|l|}
\hline French Overseas Territory & Cost of water treatment & Sources \\
\hline French Guiana & $1.3 € / \mathrm{m}^{3}$ & Office de l'eau Guyane (2016) \\
\hline Martinique & $2.57 € / \mathrm{m}^{3}$ & Dequesne et al. (2018) \\
\hline Guadeloupe & $2.00 € / \mathrm{m}^{3}$ & Dequesne et al. (2018) \\
\hline Saint-Martin & $2.01 € / \mathrm{m}^{3}$ (national cost) & Dequesne et al. (2018) \\
\hline Saint-Barthelemy & $2.01 € / \mathrm{m}^{3}$ (national cost) & Dequesne et al. (2018) \\
\hline Mayotte & $2.40 € / \mathrm{m}^{3}$ & Artelia (2013) \\
\hline
\end{tabular}




\begin{tabular}{|l|l|l|}
\hline Scattered Islands & $2.01 € / \mathrm{m}^{3}$ (national cost) & Dequesne et al. (2018) \\
\hline New Caledonia & $1.31 € / \mathrm{m}^{3}(156 \mathrm{XPF})$ & Ville de Nouméa (2017) \\
\hline Wallis and Futuna & $1.99 € / \mathrm{m}^{3}(237.32 \mathrm{XPF})$ & IEOM (2017) \\
\hline French Polynesia & $1.32 € / \mathrm{m}^{3}$ & Dardenne et al. (2011) \\
\hline
\end{tabular}




\section{Table S7}

Literature review of fish biomass in mangroves.

\begin{tabular}{|c|c|c|}
\hline Country & Fish biomass (kg/ha) & Sources \\
\hline Australia & 82 & Blaber et al., 1989 \\
\hline Australia & $\begin{array}{l}610 ; 510 ; 150 ; 460 ; 350 ; 80 ; 500 ; 100 ; 220 ; \\
160 ; 80 ; 120 ; 50 ; 70 ; 80 ; 350 ; 410\end{array}$ & Morton, 1990 \\
\hline Australia & 130 & Halliday and Young, 1996 \\
\hline Brazil & 98.5 & Barletta, 1999 \\
\hline Brazil & 21 & Barletta et al., 2003 \\
\hline Indonesia & 104 & Ronnback et al., 1999 \\
\hline Iran & $6 ; 3.8 ; 2.1$ & Shahraki et al., 2016 \\
\hline New - Caledonia & 207 & Thollot, 1992 \\
\hline Salomon Islands & 116 & Blaber et Milton, 1990 \\
\hline USA & $\begin{array}{l}58 ; 262 ; 581 ; 98 ; 30 ; 4 ; 783 ; 81 ; 48 ; 386 ; \\
521 ; 226 ; 50 ; 19 ; 13 ; 87 ; 23 ; 9 ; 264 ; 93 ; \\
34 ; 119 ; 500 ; 13 ; 9 ; 27 ; 1,081 ; 190 ; 23 ; 24 ; \\
204 ; 11 ; 40 ; 118 ; 234 ; 24 ; 579 ; 266 ; 15 ; 5 ; \\
17 ; 67 ; 17 ; 6 ; 95 ; 24 ; 18 ; 218 ; 9 ; 154 ; 112 ; \\
24 ; 4 ; 17 ; 12 ; 8 ; 13 ; 66 ; 69 ; 22 ; 2 ; 94\end{array}$ & Thayer et al., 1987 \\
\hline
\end{tabular}




\section{Table S8}

Literature review of the annual cost of producing $1 \mathrm{~kg}$ of fish through fish farming.

\begin{tabular}{|c|c|c|c|c|}
\hline Country & Produced species & $\begin{array}{l}\text { Production cost as of } \\
2017(€ / \mathbf{k g})\end{array}$ & Sources & $\begin{array}{l}2017 \text { GDP } \\
\text { PPP Per } \\
\text { capita * }\end{array}$ \\
\hline Algeria & Tilapia sp. & 1.34 & Benidiri, 2017 & $€ 13,424$ \\
\hline Bangladesh & Panga species & 0.66 & Alam, 2011 & $€ 3,064$ \\
\hline Bangladesh & $\begin{array}{l}\text { carp and SIS } \\
\text { species }\end{array}$ & $0.96 / 0.75 / 0.85$ & Ahmed, 2009 & $€ 3,064$ \\
\hline Bangladesh & NA & $1.27 / 0.88$ & Uddin and Farjana, 2012 & $€ 3,064$ \\
\hline Brazil & $\begin{array}{l}\text { Colossoma spp. and } \\
\text { Piaractus spp. }\end{array}$ & 2.42 & $\begin{array}{l}\text { Fernandes de Barros and } \\
\text { Martino, } 2012\end{array}$ & $€ 14,380$ \\
\hline Canada & NA & $5.24 / 11.39$ & Boulet et al., 2010 & $€ 41,009$ \\
\hline $\begin{array}{l}\text { Central African } \\
\text { Republic }\end{array}$ & Clarias lazera & $\begin{array}{l}2.79 / 2.93 / 2.68 / 2.63 / \\
2.48 / 2.62\end{array}$ & Lietar, 1984 & $€ 608$ \\
\hline $\begin{array}{l}\text { Central African } \\
\text { Republic }\end{array}$ & Tilapia nilotica & $\begin{array}{l}4.06 / 4.00 / 3.89 / 3.80 / \\
3.79 / 3.75 / 3.70\end{array}$ & Lietar, 1984 & $€ 608$ \\
\hline $\begin{array}{l}\text { Central African } \\
\text { Republic }\end{array}$ & $\begin{array}{l}\text { Clarias lazera and } \\
\text { Tailapia nilo }\end{array}$ & $\begin{array}{l}3.81 / 3.33 / 3.21 / 2.99 / \\
2.83 / 2.82 / 2.71 / 2.63\end{array}$ & Lietar, 1984 & $€ 608$ \\
\hline China & Carp species & 2.07 & Sharma et al., 1999 & $€ 13,273$ \\
\hline Côte d'Ivoire & $\begin{array}{l}\text { Tilapia } s p \text {. and } \\
\text { other species }\end{array}$ & 4.75 & Aboua, 2016 & $€ 3,171$ \\
\hline
\end{tabular}




\begin{tabular}{|l|l|l|l|l|}
\hline Country & Produced species & Production cost as of & Sources & 2017 GDP \\
& & No17 (€/kg) & PPP Per \\
Ghana & NA & $0.00050 / 0.00032 /$ & Asmah, 2008 & capita \\
& & $0.00062 / 0.00075 /$ & & $€ 3,840$ \\
\hline Italy & $0.00070 / 0.00039 /$ & & \\
& Sea bream or sea & $9.31 / 10.54 / 11.10 /$ & Defrancesco, 2003 & \\
& bass & $10.77 / 7.17 / 8.80 / 8.51$ & & \\
& & $/ 8.64$ & & \\
\hline
\end{tabular}

* The World Bank, World Development Indicators, 2017. GDP PPP Per capita. Retrieved from https://databank.worldbank.org/data/reports.aspx?source=2\&series=NY.GDP.PCAP.PP.CD

\section{Wave data in the French Overseas territories}

A time-series of Spectral significant wave height (m) and Spectral wave period (s) were downloaded for the year 2019 from the Copernicus marine services portal (https://resources.marine.copernicus.eu) in netcdf format. The operational global ocean analysis and forecast system of Météo-France with a resolution of 1/12 degree is providing daily analysis and 5 days forecasts for the global ocean sea surface waves

(GLOBAL_ANALYSIS_FORECAST_WAV_001_027). The time series starts on March 1st, 2016. This product includes 3-hourly instantaneous fields of integrated wave parameters from the total spectrum (significant height, period, direction, stokes drift, etc.), as well as the following partitions: the wind wave, the primary and secondary swell waves. 
We calculated the mean wave height and wave period over 2019 for each of the studied islands using the Orfeo Tool box in QGIS, and the minimum and maximum values of each parameter were extracted (Table S9).

\section{Table S9}

Minimum and maximum mean wave height and period for 2019 in the French Overseas territories

\begin{tabular}{|c|c|c|c|c|}
\hline \multirow[t]{2}{*}{$\begin{array}{l}\text { French Overseas } \\
\text { territory }\end{array}$} & \multicolumn{2}{|c|}{$\begin{array}{l}\text { Mean wave significant height } \\
\text { (m) }\end{array}$} & \multicolumn{2}{|c|}{$\begin{array}{l}\text { Wave mean period from variance spectral } \\
\text { density inverse frequency moment (second) }\end{array}$} \\
\hline & $\min$ & $\max$ & $\min$ & $\max$ \\
\hline French Guiana & 0.44 & 1.79 & 5.72 & 8.05 \\
\hline Martinique & 0.51 & 1.83 & 6.24 & 8.05 \\
\hline Guadeloupe & 0.61 & 1.84 & 6.16 & 8.05 \\
\hline Saint Martin & 0.94 & 1.32 & 5.60 & 7.13 \\
\hline Saint Barthélémy & 1.09 & 1.50 & 6.27 & 7.61 \\
\hline Mayotte & 0.61 & 1.14 & 6.44 & 8.76 \\
\hline Scattered Islands & no data & no data & no data & no data \\
\hline New Caledonia & 0.43 & 2.39 & 5.78 & 10.20 \\
\hline Wallis and Futuna & 1.58 & 1.87 & 6.02 & 8.40 \\
\hline French Polynesia & 0.93 & 2.19 & 8.22 & 11.73 \\
\hline
\end{tabular}




\section{Figure S3}

Mean height and periods of waves over New-Caledonia in 2019, with height ranging from 0.43 to $2.39 \mathrm{~m}$ and period ranging from 5.78 to $10.2 \mathrm{~s}$.

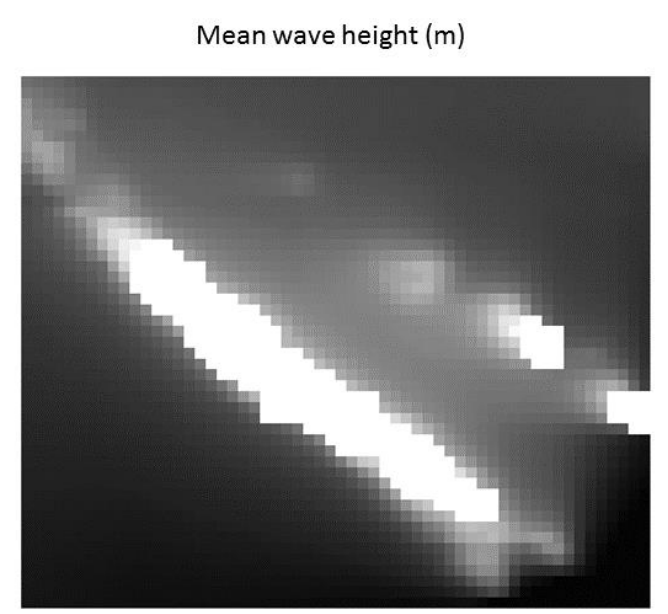

0,43
Mean wave period $(s)$

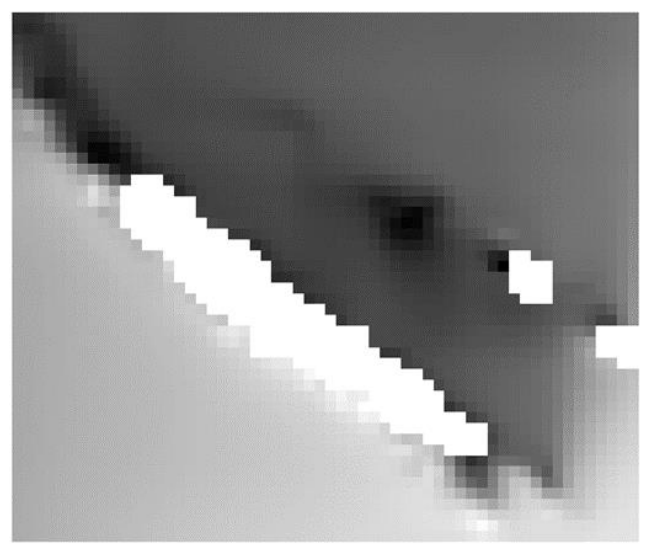

5,78

10,2

New-Caledonia

\section{References}

Aboua, C. (2016). Resource efficiency and economic efficiency in fish farming in the south-east of Côte d'Ivoire. 5th International Conference of African Association of Agricultural Economists, Addis Ababa, Ethiopia. Retrieved from:

https://ageconsearch.umn.edu/record/249307/files/F39.\%20Efficiency\%20of\%20fish\%20farming\%20in \%20Cote\%20d_\%20Ivoire.pdf

Ahmed, N. (2009). The sustainable livelihoods approach to the development of fish farming in rural Bangladesh. Journal of International Farm Management, 4(4), 1-18. 
Alam, F. (2011). Measuring technical, allocative and cost efficiency of pangas (Pangasius hypophthalmus: Sauvage 1878) fish farmers of Bangladesh. Aquaculture Research, 42(10), 1487-1500. doi: 10.1111/j.1365-2109.2010.02741.x

Alongi, D., Trott, L., Wattayakorn, G., \& Clough, B. (2002). Below-ground nitrogen cycling in relation to net canopy production in mangrove forests of southern Thailand. Marine biology, 140(4), 855-864.

Artelia (2013). Analyse financière rétrospective et prospective de l'activité du SIEAM, rapport final provisoire, AFD - Agence Française de Développement, Artélia, 85 p. Retrieved from: https://www.pseau.org/outils/ouvrages/afd_artelia_analyse_financiere_prospective_et_retrospective_de_1 _activite_du_sieam_2012.pdf

Asmah, R. (2008). Development potential and financial viability of fish farming in Ghana. (PhD), University of Stirling. Retrieved from: http://hdl.handle.net/1893/461

Barletta, M. (1999). Seasonal changes of density, biomass and species composition of fishes in different habitats of the Caeté estuary (North Brazil Coast-East Amazon). ZMT Contribution, 7.

Barletta, M., Barletta-Bergan, A., Saint-Paul, U., \& Hubold, G. (2003). Seasonal changes in density, biomass, and diversity of estuarine fishes in tidal mangrove creeks of the lower Caeté Estuary (northern Brazilian coast, east Amazon). Marine Ecology Progress Series, 256, 217-228.

Benidiri, R. (2017). Création d'un projet piscicole. (Master Degree), Université Abou bekr Belkaid, Tlemcen. Retrieved from: http://dspace.univ-tlemcen.dz/bitstream/112/11553/1/Ms.ELN.Benidiri.pdf Blaber, S., Brewer, D., \& Salini, J. (1989). Species composition and biomasses of fishes in different habitats of a tropical northern Australian estuary: their occurrence in the adjoining sea and estuarine dependence. Estuarine, coastal and shelf science, 29(6), 509-531.

Blaber, S., \& Milton, D. (1990). Species composition, community structure and zoogeography of fishes of mangrove estuaries in the Solomon Islands. Marine biology, 105(2), 259-267.

Black, K. P., Baba, M., Mathew, J., Kurian, N. P., Urich, P., Narayan, B., \& Stanley, D. O. (2017). Climate Change Adaptation Guidelines for Coastal Protection and Management in India. In K. P. Black, M. Baba \& S. B. Parsons (Eds.), $(83+331$ pp.): FCG ANZDEC (New Zealand) for the Global Environment Facility and Asian Development Bank. 
Boulet, D., Struthers, A., \& Gilbert, E. (2010). Etude de faisabilité financière de différentes options de parcs clos pour le secteur de l'aquaculture en Colombie-Britannique: Innovation et Stratégies Sectorielles, Direction Générale de la Gestion de l'Aquaculture, Ministère des Pêches et Océans, Canada, 58 pp.

Climate ADAPT - The European Climate Adaptation Platform (2015). Adaptation option - Groynes, breakwaters and artificial reefs. Retrieved from: https://climateadapt.eea.europa.eu/metadata/adaptation-options/groynes-breakwaters-and-artificial-reefs

Corredor, J. E., \& Morell, J. M. (1994). Nitrate depuration of secondary sewage effluents in mangrove sediments. Estuaries, 17(1), 295-300.

Corredor, J. E., Morell, J. M., \& Bauza, J. (1999). Atmospheric nitrous oxide fluxes from mangrove sediments. Marine Pollution Bulletin, 38(6), 473-478.

Dardenne, B., Roger, G., Petitzon, G., de Giudici, P., \& Picart, G. (2011). Le coût économique des déficiences de l'assainissement en Polynésie Française. Rapport ASPA-Utilities pour l'Agence Française du Développement, 106 pp. Retrieved from : https://www.pseau.org/outils/biblio/resume.php?d=2963\&l=fr

Dawson, E., Chen, D., Chinn, T., Feng, T., Li, T., Petrocelli, T., Rosa, J., Rousseva, N., Tadesse, S., Zepeda, G., \& Sarrinikolaou, G. (2013). Opportunities for climate resilience, The beaches of Stamford, Connecticut: The Integrative Capstone Workshop in Sustainability Management, Columbia University, for the City of Stamford Land Use Bureau, 43 pp.

Defrancesco, E. (2003). The beginning of organic fish farming in Italy (pp. 25). Milano: Fondazione Eni Enrico Mattei (FEEM), 25 pp.

Delangue, J., \& Teillac-Deschamps, P. (2018). Le service de régulation de l'érosion côtière en Aquitaine (pp. 64). Paris: Service de l'économie, de l'évaluation et de l'intégration du développement durable, Ministère de la Transition Ecologique et Solidaire, 64 pp.

Dequesne, J., Bréjoux, E., Debuf, O., \& Binjamin, F. (2018). Observatoire des services publics d'eau et d'assainissement. Panorama des services et de leur performance en 2015. 81 pp. Retrieved from: http://www.services.eaufrance.fr/docs/synthese/rapports/Rapport_SISPEA_2015_complet_DEF.pdf 
Emerton, L., Baig, S., \& Saleem, M. (2009). Valuing Biodiversity. The economic case for biodiversity conservation in the Maldives, $86 \mathrm{pp}$.

Fernandes, S. O., Bharathi, P., Bonin, P. C., \& Michotey, V. D. (2010). Denitrification: an important pathway for nitrous oxide production in tropical mangrove sediments (Goa, India). Journal of environmental quality, 39(4), 1507-1516. doi:10.2134/jeq2009.0477

Fernandes de Barros, A., \& Martins, M. I. E. G. (2012). Performance and economic indicators of a large scale fish farming in Mato Grosso, Brazil. Revista Brasileira de Zootecnia, 41, 1325-1331.

Field Studies Council (2012). Coastal Processes Day - Criccieth. Retrieved from: https://www.fieldstudies-council.org/documents/centres/rhyd-y-creaua/resources/coasts/criccieth.pdf

Gaudieux, A.-L., Diaz, B., Houssaye, C., Rogelja, T., Denis, B., Marin, I., Coutos Thevenos, M., Facon, M., \& Garnier, R. (2016). Renforcement du littoral et mise en place d'aires de sécurité aux extrémités des pistes (RESA) Rapport définitif. Saint-Denis La Réunion: SA Aéroport de la Réunion Roland Garros, $218 \mathrm{pp}$.

Halliday, I. A., \& Young, W. R. (1996). Density, biomass and species composition of fish in a subtropical Rhizophora stylosa mangrove forest. Marine and Freshwater Research, 47(4), 609-615.

Hillen, M. M., Jonkman, S. N., Kanning, W., Kok, M., Geldenhuys, M. A., \& Stive, M. J. F. (2010). Coastal defence cost estimates: Case study of the Netherlands, New Orleans and Vietnam.

Communications on Hydraulic and Geotechnical Engineering, No. 2010-01, 87.

Hudson, T., Keating, K., \& Pettit, A. (2015). Delivering benefits through evidence, Cost estimation for coastal protection - Summary of evidence. Bristol, $46 \mathrm{pp}$.

IEOM (2017). Wallis et Futuna - Rapport annuel 2016. Institut d'Emission d'Outre-Mer, 142 pp.

Retrieved from : https://www.ieom.fr/IMG/pdf/rapport_annuel_ieom_2016_wallis-et-futuna.pdf.

Iizumi, H. (1986). Soil nutrient dynamics. Workshop on Mangrove Ecosystem Dynamics. UNDP/UNESCO Regional Project (RAS/79/002), New Delhi, 171-180.

King, P. G., McGregor, A. R., \& Whittet, J. D. (2011). The economic costs of sea-level rise to California beach communities. Fresno, 97 pp. 
Lietar, C. (1984). Rentabilité d'une ferme piscicole commerciale en République Centrafricaine. Bangui: Haut Commissariat Chargé des Eaux, Forêts, Chasses, Pêches et du Tourisme.

Moberg, F., \& Rönnbäck, P. (2003). Ecosystem services of the tropical seascape: interactions, substitutions and restoration. Ocean \& Coastal Management, 46(1), 27-46. doi: https://doi.org/10.1016/S0964$5691(02) 00119-9$

Morton, R. (1990). Community structure, density and standing crop of fishes in a subtropical Australian mangrove area. Marine biology, 105(3), 385-394.

Office de l'eau Guyane (2016). Prix de l'eau 2015 d'après les factures standardisées aux $120 \mathrm{~m}^{3} .2 \mathrm{p}$. Retrieved from: http://eauguyane.fr/images/publications/eau-potable/img2-

Prix_Eau_Potable_2015_120m.pdf

Perez, M. L., Sajise, A. J. U., Ramirez, P. J. B., Arias, J. K. B., Purnomo, A. H., Dipasupil, S. R., Regoniel, P. A., Nguyen, K. A. T., Zamora, G. J. (2013). Economic analysis of climate change adaptation strategies in selected coastal areas in Indonesia, Philippines and Vietnam, Penang, Malaysia, 27 pp.

Rivera-Monroy, V. H., \& Twilley, R. R. (1996). The relative role of denitrification and immobilization in the fate of inorganic nitrogen in mangrove sediments (Terminos Lagoon, Mexico). Limnology and Oceanography, 41(2), 284-296.

Rönnbäck, P. (1999). The ecological basis for economic value of seafood production supported by mangrove ecosystems. Ecological economics, 29(2), 235-252.

Shahraki, M., Saint-Paul, U., Krumme, U., \& Fry, B. (2016). Fish use of intertidal mangrove creeks at Qeshm Island, Iran. Marine Ecology Progress Series, 542, 153-166.

Sharma, K. R., Leung, P., Chen, H., \& Peterson, A. (1999). Economic efficiency and optimum stocking densities in fish polyculture: an application of data envelopment analysis (DEA) to Chinese fish farms. Aquaculture, 180(3-4), 207-221.

Silva, R., Lithgow, D., Esteves, L. S., Martínez, M. L., Moreno-Casasola, P., Martell, R., Pereira, P., Mendoza, E., Campos-Cascaredo, A., Winckler Grez, P., Osorio, A. F., Osorio-Cano, J. D., \& Rivillas, 
G. D. (2017). Coastal risk mitigation by green infrastructure in Latin America. Proceedings of the Institution of Civil Engineers: Maritime Engineering, 170(2), 39-54.

Thayer, G. W., Colby, D. R., \& Hettler Jr, W. F. (1987). Utilization of the red mangrove prop root habitat. Marine Ecology-Progress Series, 35, 25-38.

Thollot, P. (1992). Importance of mangroves for Pacific reef fish species, myth or reality. Paper presented at the Proceedings of the 7th International Coral Reef Symposium, 2, 934-941

Tresca, A. (2015). Etude de faisabilité d'un aménagement de stabilisation à court terme de la dune d'Aval. Dunkerque: Antenne IDRA Nord pour le Pôle Métropolitain de la Côte d'Opale, 93 pp.

Uddin, M., \& Farjana, I. (2013). An economic study of low lying inland fish farming in selected areas of Kishoreganj district. Progressive Agriculture, 23(1-2), 81-90. doi: https://doi.org/10.3329/pa.v23i12.16619

van Rijn, L. C. (2011). Coastal erosion and control. Ocean \& Coastal Management, 54(12), 867-887. doi: https://doi.org/10.1016/j.ocecoaman.2011.05.004

Ville de Lacanau and GIP Littoral Aquitain (2015). Etude de lutte active pour le littoral canaulais, 18 pp. Ville de Nouméa (2017). Rapport sur le prix et la qualité de l'eau potable - Synthèse Exercice 2017. Ville de Nouméa. 40 pp. 